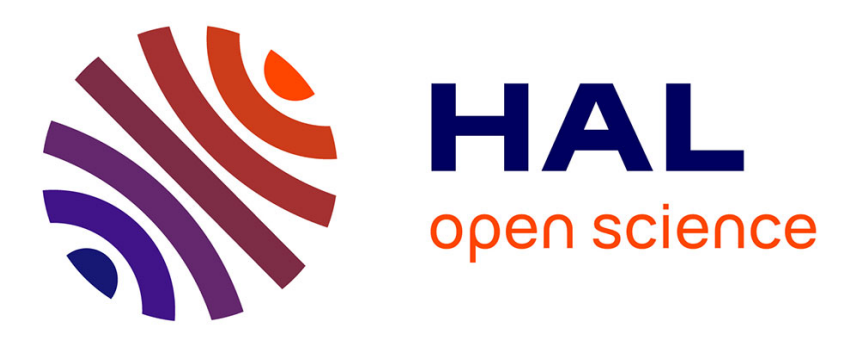

\title{
Ammonium pyrrolidine dithiocarbamate adsorption on copper surface in neutral chloride media
}

Wafaa Qafsaoui, Martin W. Kendig, Suzanne Joiret, Hubert Perrot, Hisasi Takenouti

\section{- To cite this version:}

Wafaa Qafsaoui, Martin W. Kendig, Suzanne Joiret, Hubert Perrot, Hisasi Takenouti. Ammonium pyrrolidine dithiocarbamate adsorption on copper surface in neutral chloride media. Corrosion Science, 2016, 106, pp.96-107. 10.1016/j.corsci.2016.01.029 . hal-01297862

\section{HAL Id: hal-01297862 https: / hal.sorbonne-universite.fr/hal-01297862}

Submitted on 5 Apr 2016

HAL is a multi-disciplinary open access archive for the deposit and dissemination of scientific research documents, whether they are published or not. The documents may come from teaching and research institutions in France or abroad, or from public or private research centers.
L'archive ouverte pluridisciplinaire HAL, est destinée au dépôt et à la diffusion de documents scientifiques de niveau recherche, publiés ou non, émanant des établissements d'enseignement et de recherche français ou étrangers, des laboratoires publics ou privés. 


\title{
Ammonium pyrrolidine dithiocarbamate adsorption
}

\section{on copper surface in neutral chloride media}

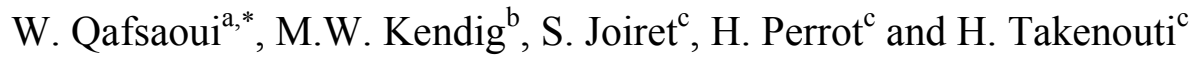 \\ a Laboratoire de l'Eau et de l'Environnement, Faculté des Sciences d'El Jadida, BP 20, \\ 24000 El Jadida, Morocco. wqafsaoui@gmail.com \\ ${ }^{\mathrm{b}}$ Kendig Research Associates LLC, 496 Hillsborough, Thousand Oaks, CA 91361. \\ USA, martin.kendig@verizon.net \\ ${ }^{\mathrm{c}}$ Sorbonne Universités, UPMC Univ Paris 06, CNRS, Laboratoire Interfaces et Systèmes \\ Electrochimiques, 4 place Jussieu, F-75005, Paris, France \\ suzanne.joiret@upmc.fr; hubert.perrot@upmc.fr; hisasi.takenouti@upmc.fr
}

\begin{abstract}
Adsorption of ammonium pyrrolidine dithiocarbamate (PDTC) on copper surface in 0.2 and $30 \mathrm{~g} \mathrm{~L}^{-1} \mathrm{NaCl}$ media was investigated by different electrochemical methods and surface analyses. The results from electrochemical measurements showed that PDTC adsorbs rapidly on copper surface and revealed a marked effect of mixed inhibition. Surface analyses confirm the adsorption of PDTC on copper and the formation of a $\mathrm{Cu}-\mathrm{PDTC}$ complex through the S atoms of PDTC. At high concentrations PDTC prevents oxides and cuprous chloride formation. XPS results showed that PDTC bonds with cuprous species indicating the formation of $\mathrm{Cu}^{\mathrm{I}}$-PDTC complex.
\end{abstract}

Keywords: copper, polarization, EIS, Raman spectroscopy, XPS, neutral inhibition.

* Corresponding author: Fax: +212.523 3421 87; E-mail: wqafsaoui@gmail.com 


\section{Introduction}

Formation of insulating and barrier films on copper surface has an importance in the corrosion protection of this metal in various environments, namely in the mining industry as flotation agents [1] and in the preservation of archaeological and cultural artefacts [2]. Moreover, addition of copper as hardener in structural materials such as AA 2000 series aluminium alloys makes these materials highly susceptible to localized corrosion due to galvanic coupling between the copper-rich intermetallic phase and the aluminium matrix. Efficient corrosion inhibitors such as the hexavalent chromates present an environmental hazard. Therefore, a need exists for non-hazardous corrosion inhibitors that will specifically interact with the $\mathrm{Cu}$-bearing phases. The selective adsorption of some inhibitors on copperrich precipitates may enhance corrosion resistance of these alloys [3-8]. In addition, inhibition of $\mathrm{Cu}$ corrosion by thin adsorbed films plays a crucial role in chemical mechanical planarization (CMP) used in fabrication of ultra large scale integration devices [9]. In general, copper corrosion and its inhibition have great importance to the electronics industry due to the ubiquitous presence of copper metallization.

Considerable work related to the inhibition of copper corrosion by organic molecules dating back to the 1960-1975 time period [10,11] has focused on the interaction between $\mathrm{Cu}$ and Benzotriazole (BTAH). Finšgar and Milošev have recently provided a review of the corrosion inhibition of $\mathrm{Cu}$ by BTAH who emphasize a mechanism involving the formation of a $\mathrm{Cu}^{\mathrm{I}}$-BTA complex with additional interaction with $\mathrm{Cl}^{-}$[12].

A recent review of organic inhibitors for copper corrosion, by Antonijovic and Petrovic [13], points out the importance of heteroatoms such as N, S, or P in organic compounds to enable good corrosion inhibition of $\mathrm{Cu}$. Indeed, there are numerous reports on the efficiency of sulphur-containing molecules for the corrosion inhibition of $\mathrm{Cu}$ in a variety of media [14-21] and through the use of self-assembled monolayer [22-25]. Ohsawa and 
Suëtaka explained that the inhibition of $\mathrm{Cu}$ corrosion in $0.1 \mathrm{M} \mathrm{Na}_{2} \mathrm{SO}_{4}$ by mercaptobenzothiazole (MBT) in terms of the formation of a protective $\mathrm{Cu}^{\mathrm{I}}-\mathrm{MBT}$ film [18]. Tansug et al. concluded also in the study of a methyl mercapto-phenyl amino butanate to the corrosion inhibition of $\mathrm{Cu}$ in $0.1 \mathrm{M} \mathrm{HCl}$ that a $\mathrm{Cu}^{\mathrm{I}}$-organo metallic film provides the corrosion protection [20].

Several studies considered the dithio compound, di-mercaptothiadiazole (DMCT), as an efficient inhibitor for $\mathrm{Cu}$ [26-33]. Qin et al. showed the DMCT self-assembled monolayer (SAM) as effective inhibitor film [26]. Others showed that DMCT inhibits the oxygen reduction reaction $(\mathrm{ORR})$ on $\mathrm{Cu}$ in $0.5 \mathrm{M} \mathrm{NaCl}$ to a similar degree to that of $\mathrm{Ce}^{3+}$ ions [32]. The detailed interaction of organic sulphur compounds with $\mathrm{Cu}$ surfaces remains determining in light of the role that $\mathrm{Cu}$ plays in the corrosion of the technically important $\mathrm{Cu}$-bearing-AA 2024 as exemplified by the report of Williams et al. who attribute the corrosion inhibition to the formation of an insoluble $\mathrm{Cu}^{\mathrm{II}}$-precipitate covering the $\mathrm{Cu}$-rich surface [34].

An important class of dithio compounds that has both nitrogen and di-thiol functionality are the di-alkyl di-thiocarbamates. They are schematically shown in Fig. 1a. They were recently shown as good corrosion inhibitors for $\mathrm{Cu}$. For instance, piperidinedithiocarbamate as well as its $\mathrm{Cu}^{\mathrm{II}}$-complex showed good inhibitive efficiency of $\mathrm{Cu}$ corrosion in $1.5 \% \mathrm{NaCl}$ [35]. N,N diethyl di-thiocarbamate compound (where the two $\mathrm{R}$ moieties in Fig. 1a are ethyl) inhibits pitting corrosion of the Cu-containing alloy AA 2024 through the formation of a protective film on the $\mathrm{Cu}$-rich intermetallics [32]. These authors attribute the corrosion inhibition to the formation of an insoluble $\mathrm{Cu}^{\mathrm{II}}$-chelate film. Indeed, the ability of water soluble dithiocarbamates to chelate transition metal ions to form highly waterinsoluble complexes provides the basis for their use as pre-concentrators for metal extraction or flotation for chemical analysis or remediation [36]. 
The base of pyrrolidine dithiocarbamate (PDTC), usually in the form of the ammonium salt, provides a readily available and stable form of the dithiocarbamate structure. In the case of PDTC an alkyl ring (Fig. 1b) rather than two separate alkyl moieties (Fig. 1a) forms the structure with the dithiocarbamate functionality. This material has a good water solubility as the free base, but has low solubility when forming a chelate with a metal cation [36]. PDTC is, therefore, expected to provide good inhibition of $\mathrm{Cu}$ corrosion in near neutral media. Indeed, in a previous work we demonstrated that this compound effectively inhibits the corrosion of $\mathrm{Cu}$ in $0.5 \mathrm{M} \mathrm{NaCl}$, for concentrations as low as $10^{-3} \mathrm{M}$ by forming a stable Cu-PDTC complex film [28]. Moreover, PDTC is a non-toxic compound for the inhibition of steel piping corrosion [37].

As mentioned above, PDTC is non-toxic and non-hazardous. In fact, the PDTC base as well as its $\mathrm{Cu}$ chelate has many biomedical applications primarily as an antioxidant and antiinflammatory. PDTC and particularly its complexes with $\mathrm{Cu}$ ions inhibits a nuclear factorkappa B (NF-кB), a protein complex whose incorrect regulation was linked to cancer, inflammatory [38], autoimmune diseases, septic shock, viral infection, and lack of immune development [39].

The present work focuses on the inhibition mechanism of $\mathrm{Cu}$ corrosion in 0.2 and 30 $\mathrm{g} \mathrm{L}^{-1} \mathrm{NaCl}$, by the dithiocarbamide base PDTC. These two concentrations represent respectively the chloride content in natural soil water and sea waters. By hypothesis, the group $\mathrm{S}=(\mathrm{CN})-\mathrm{S}$ - may react with the $\mathrm{Cu}$ surface in some way to form a protective layer which hinders the oxygen reduction and slows down the anodic dissolution of $\mathrm{Cu}$ [28]. It is not clear, however, whether the reaction with $\mathrm{Cu}$ is through the $\mathrm{S}$ atom, the $\mathrm{N}$ atom or both. Besides, there is no overall agreement as for the degree of oxidation of the $\mathrm{Cu}$ interacting with the PDTC base. For various inhibitors as quoted above, many authors consider that the Scontaining inhibitors react to form a $\mathrm{Cu}^{\mathrm{I}}$ complex film. On the other hand, Williams et al. 
postulate a three dimensional $\mathrm{Cu}^{\mathrm{II}}$ film as providing the corrosion protection in $\mathrm{Cu}$-containing $\mathrm{Al}$ alloys [34]. It is also crucial to know whether the inhibition is through a three dimensional film or two dimensional adsorbed surface layer. These questions can be addressed using a number of surface analytical methods including XPS, SEM/EDX, XRD, surface Raman micro-spectroscopy, and electrochemical impedance spectroscopy (EIS). Results will eventually enable the development of a molecular model for the inhibition process possibly leading to identification of additional inhibitors.

\section{Experimental methods}

\subsection{Chemicals and materials}

The disk electrode was made of a $5 \mathrm{~mm}$ diameter cylinder rod of pure copper (Goodfellow, 99.999\% of quality). The rod was then embedded into allylic resin or a thermal shrinking sheath. Prior to this preparation, the lateral part of the cylinder was coated with a cataphoretic paint (PGG W975 + G323) to avoid the electrolyte infiltration in the lateral part of the cylinder rod. The electrode surface was then abraded under water flow just before experiments, by rotating silicon carbide paper up to 1200 grade, and then rinsed thoroughly with deionised water.

The working electrode was set close to the centre of the cylindrical electrolysis cell under stationary conditions without electrolyte stirring. The reference electrode was a calomel electrode in saturated $\mathrm{KCl}$ (SCE). The counter electrode was a platinum grid of a large surface area set close to the cell wall.

The blank corrosion test solution was 0.2 or $30 \mathrm{~g} \mathrm{~L}^{-1} \mathrm{NaCl}$, to which $10^{-2} \mathrm{~mol} \mathrm{~L}^{-1}$ of PDTC $\left(\mathrm{C}_{5} \mathrm{H}_{9} \mathrm{NS}_{2}, \mathrm{M}=147.26 \mathrm{~g} \mathrm{~mol}^{-1}\right.$, supplied by Sigma $\left.{ }^{\circledR}\right)$ was added as inhibitor. For each experiment, $100 \mathrm{~mL}$ of electrolyte was used. The corrosion test was carried out under temperature control $\left(20^{\circ} \mathrm{C}\right)$ without purging dissolved oxygen. 


\subsection{Electrochemical measurements}

Electrochemical measurements were carried out in a conventional three-electrode cell, using a Gamry potentiostat/galvanostat Model FAS-1 or 300C. The working disk electrode was faced towards the cell bottom.

Polarization measurements were performed after 24 hours immersion in the test solution with or without PDTC. The curves were plotted from two independent measurements in a new test solution for each run: one from the open circuit potential towards about $-1.5 \mathrm{~V} /$ $\mathrm{SCE}$, and another from the open circuit potential to about $+1.5 \mathrm{~V} / \mathrm{SCE}$ at a potential scan rate of $10 \mathrm{mV} \mathrm{s}^{-1}$. Three replica experiments were carried out for each experimental condition.

The impedance measurements were performed with $10 \mathrm{mV}_{\text {rms }}$ from $100 \mathrm{kHz}$ to $1 \mathrm{~Hz}$ or to $10 \mathrm{mHz}$ by 10 points per decade. The EIS measurements were carried out at different immersion times in the test solutions with PDTC and after 24 hours immersion in the blank solutions. The data were fitted by Simad software, a lab-made software using a simplex regression method.

\subsection{Surface analyses}

\subsubsection{Scanning Electron Microscopy (SEM) / Energy Dispersive Spectroscopy (EDS)}

The surface morphology of the electrodes was observed with a Leica Stereoscan 440 scanning electron microscopy (SEM), and element analyses were performed with an energy dispersive X-ray analyzer (EDX; Princeton Gamma-Tech ${ }^{\circledR}$ ). 


\subsubsection{X-ray diffraction (XRD)}

XRD spectra of the films formed on copper surface, without or with PDTC, were collected with an X-ray diffraction (XRD) (Phillips PANanalytical X'Pert Pro) using Cu Ka radiation $(\lambda=1.54184 \AA)$.

\subsubsection{Raman micro-spectroscopy}

Raman micro-spectroscopy analyses were carried out with a Labram-Jobin-Yvon spectrometer. The samples were irradiated with a He-Ne laser at $\lambda=632.8 \mathrm{~nm}$. The laser power was varied between 0.1 and $1 \mathrm{~mW}$ to avoid any thermal effect on sample during the analyses. A confocal microscope was used and the investigated area was limited to $5 \mu \mathrm{m}^{2}$ using an Olympus 80× Ultra Long Working Distance (ULWD) objective lens.

\subsubsection{X-ray photoelectron spectroscopy (XPS)}

XPS experiments were performed with an ESCA + Omicron. An Al Ka anode (1486.6 $\mathrm{eV}$ ) was used, operated at $300 \mathrm{~W}$. The spectrometer was calibrated against $\mathrm{C}_{1 \mathrm{~s}}$ at $284.7 \pm 0.1$ $\mathrm{eV}$. Data were acquired with $0.1 \mathrm{eV}$ steps. The detection angle was generally normal to the surface. The pressure in the UHV analysis chamber was less than $10^{-7} \mathrm{~Pa}$.

\section{Results and discussion}

\subsection{Electrochemical measurements}

\subsubsection{Potentiodynamic polarization}

Fig. 2a compares the corrosion potential $\left(E_{c o r r}\right)$ values as a function of immersion time of the copper electrode in presence or not of $10^{-2} \mathrm{~mol} \mathrm{~L}^{-1}(10 \mathrm{mM})$ PDTC in 0.2 or $30 \mathrm{~g} \mathrm{~L}^{-1}$ $\mathrm{NaCl}$. It is seen that without PDTC $E_{\text {corr }}$ varies a few tens $\mathrm{mV}$ during the whole immersion time. In contrast, the corrosion potential of $\mathrm{Cu}$ in presence of PDTC decreases significantly during the first immersion times, as can be seen in the insert, then increases progressively. 
This suggests that PDTC adsorbs readily on the copper surface thereby lowering the potential to more cathodic values by decreasing the partial cathodic current density.

The results of potentiondynamic measurements are given in Fig. $2 b$ for copper in 0.2 or $30 \mathrm{~g} \mathrm{~L}^{-1} \mathrm{NaCl}$ in the absence and the presence of $10 \mathrm{mM}$ PDTC. The anodic and cathodic characteristics were collected by independent cathodic and anodic scan experiments as stated above.

In inhibitor free solution, current densities are much higher in the $30 \mathrm{~g} \mathrm{~L}^{-1}$ solution. Such a curve is typical of copper electrode in highly concentrated chloride media. It shows a cathodic peak around $-0.9 \mathrm{~V} / \mathrm{SCE}$ superimposed to the diffusion-limited current of oxygen reduction reaction (ORR). The potential of this peak is in agreement with the reduction of $\mathrm{Cu}_{2} \mathrm{O}[28,40]$ formed by hydrolysis of the cuprous corrosion products. The anodic behaviour is largely described in the literature [41-43]: the Tafel region at lower over-potentials extending to a peak current density $\left(j_{p e a k}\right.$, located around $-0.05 \mathrm{~V} / \mathrm{SCE}$ ) due to the dissolution of copper into $\mathrm{Cu}^{+}$, then a region of decreasing currents until a minimum value $\left(j_{\min }\right)$ due to $\mathrm{CuCl}$ formation and finally, there appears a region of sudden increase in current density leading to a limiting value $\left(j_{\text {lim }}\right)$, as a result of $\mathrm{CuCl}_{2}^{-}$formation.

In low chloride concentration $\left(0.2 \mathrm{~g} \mathrm{~L}^{-1}\right)$, no peak appears in the anodic branch because of the absence or minimal quantity of $\mathrm{CuCl}$ formed. However, $\mathrm{Cu}_{2} \mathrm{O}$ forms during immersion since its reduction peak during the cathodic scan is observed at nearly the same potential $(-0.9 \mathrm{~V} / \mathrm{SCE})$. On the other hand, $E_{\text {corr }}$ is located at more anodic potentials due to the low aggressiveness of this solution towards copper [42].

Addition of $10 \mathrm{mM}$ PDTC to 0.2 or $30 \mathrm{~g} \mathrm{~L}^{-1} \mathrm{NaCl}$ solution significantly decreases both the anodic and cathodic current densities. The anodic current peak disappears and broad current plateaus are obtained mainly for the low chloride concentrations. It is likely that the 
PDTC molecules have adsorbed onto the copper surface, which could decrease the anodic reaction rate of the initial step making difficult further corrosion propagation. Moreover, no $\mathrm{Cu}_{2} \mathrm{O}$ reduction peak appears for the $30 \mathrm{~g} \mathrm{~L}^{-1} \mathrm{NaCl}+10 \mathrm{mM}$ PDTC likely due to the rapid adsorption of PDTC which prevents oxide formation. In contrast, $\mathrm{Cu}_{2} \mathrm{O}$ forms in the presence of PDTC in $0.2 \mathrm{~g} \mathrm{~L}^{-1} \mathrm{NaCl}$ and may correspond to the $E_{\text {corr }}$ peak observed in Fig. 2a after 2 hours of immersion. In any case, PDTC adsorbs on $\mathrm{Cu}$ surface in chloride media and slows down the kinetics of both cathodic and anodic processes.

Corrosion parameters; $j_{c o r r}, E_{c o r r}, b_{a}$ and $b_{c}$ respectively the corrosion current density, corrosion potential, the Tafel slope of anodic and cathodic process are evaluated from SternGeary relationship [44] using non-linear least-square regression method at $E_{\text {corr }} \pm 50 \mathrm{mV}$. Table 1 summarizes the results. $j_{\text {corr }}$ values decrease significantly in the presence of PDTC for both high and low chloride concentrations. At the same time, $b_{a}$ values substantially increase when PDTC is present in both chloride media. In contrast, $b_{c}$ is not affected by addition of PDTC to $0.2 \mathrm{~g} \mathrm{~L}^{-1} \mathrm{NaCl}$ and only slightly increases (in absolute value) in $30 \mathrm{~g} \mathrm{~L}^{-1} \mathrm{NaCl}$ containing PDTC.

Polarization resistance $R_{p}$ values are related to the corrosion current density $j_{\text {corr }}$, through the Stern-Geary equation:

$$
\boldsymbol{j}_{\text {corr }}=\frac{\boldsymbol{b}_{a} \boldsymbol{b}_{c}}{2.303\left(\boldsymbol{b}_{c}-\boldsymbol{b}_{a}\right) \boldsymbol{R}_{p}}
$$

where $b_{a}$ and $b_{c}$ are respectively the anodic and cathodic Tafel slopes.

The higher values of $R_{p}$ (table 1) are obtained in the presence of PDTC suggesting the formation of a protective layer on the copper surface.

The inhibitor efficiency $E$ in percent was determined from the following relationship:

$$
\boldsymbol{E}=100 \frac{\boldsymbol{j}_{\text {corr }}^{0}-\boldsymbol{j}_{\text {corr }}}{\boldsymbol{j}_{\text {corr }}^{0}}
$$


where $j_{\text {corr }}^{0}$ and $j_{\text {corr }}$ denote the corrosion currents densities in absence and in presence of PDTC, respectively. The inhibiting efficiency is significant particularly in the low chloride concentrated medium.

Clearly, PDTC serves as a good mixed inhibitor on copper surface in neutral chloride media, meaning that it slows down both the rate of the oxidation reaction and that of the cathodic reaction, typically oxygen reduction. In low chloride environments, it adsorbs rapidly on $\mathrm{Cu}$ surfaces to limit the growth of a non protective oxide. The change in the anodic process is evidenced by an increase in the apparent Tafel slope.

\subsubsection{EIS measurements}

An interaction between PDTC and $\mathrm{Cu}$ surface takes place throughout the first minutes of immersion as can be seen in the insert in Fig. 2a. $E_{c o r r}$ shifts significantly and sharply towards more cathodic values returning then, markedly, towards anodic direction. PDTC may thus adsorb on the cathodic sites first at the immersion. The increase of $E_{\text {corr }}$ may be explained as well by PDTC desorption from the cathodic sites or by its adsorption on the anodic ones. For bring to light about the PDTC adsorption on copper, EIS experiments were carried out during the first hours of immersion in 0.2 or $30 \mathrm{~g} \mathrm{~L}^{-1} \mathrm{NaCl}$ containing $10 \mathrm{mM}$ PDTC. Changes of the charge transfer resistance during the very early moments of immersion may help understanding PDTC interaction with $\mathrm{Cu}$ surface. For the former, $j_{\text {corr }}$ increases whereas the latter makes $j_{\text {corr }}$ smaller. The frequency domain was limited to high and medium values $(10 \mathrm{kHz}$ to $1 \mathrm{~Hz})$ to carry out measurements in short intervals of time. The measurements were performed every 100 seconds within the first hour and every 10 minutes during the following hours.

Examples of the obtained Nyquist diagrams are shown in Fig. 3, where symbols represent experimental data and crosses the fitted data. The diagrams present a flattened semi- 
circle typical for copper or copper alloy electrode in chloride media in the presence of an inhibitor, a $\mathrm{CuCl}$ or a patina layer $[28,45,46]$. Though only one capacitive loop can be seen clearly, two capacitive contributions are necessary to reproduce suitably the experimental spectra. Therefore, the equivalent circuit model illustrated in Fig. 4 was used to analyze the impedance characteristics.

The physical nature of the circuit elements is allocated as follows.

$a-R_{s}$ : Solution resistance.

$b$ - The high frequency loop $R_{f}-C_{f}$ :

$R_{f}$ : Film resistance representing the resistance against the access of aggressive ions through the pores of the surface film.

$C_{f}$ Film capacitance due to the dielectric nature of the surface film.

$c$ - The medium frequency loop $R_{t}-C_{d}$ :

$R_{t}$ : Charge transfer resistance describing the sum of all charge transfer processes taking place at the electrode interface.

$C_{d}$ : Double layer capacitance at the electronic conducting and ionic conducting interface.

$d-n_{f}, n_{d}$ : coefficients representing the depressed feature of the capacitive loops in Nyquist diagrams $[47,48]$.

Results of the fitted parameters for the highest $\left(R_{f}, C_{f}\right)$ and the medium $\left(R_{t}, C_{d}\right)$ frequency loops are presented in Fig. 5 and Fig. 6, respectively.

Note that during the entire immersion time studied and whatever $\mathrm{Cl}^{-}$ions concentration, $R_{f}$ increases in agreement with the formation of a protective film on $\mathrm{Cu}$ surface. Besides, the decrease of $C_{f}$ with immersion time indicates thickening of the surface film. Similar changes are observed for $R_{t}$ and $C_{d}$ suggesting that during immersion, the charge transfer process becomes slower and the surface area in contact with conducting species 
smaller. These results corroborate and explain $E_{\text {corr }}$ variation during the immersion time studied (Fig. 1a). Indeed, all along the initial decreasing step of $E_{c o r r}, R_{t}$ values increase progressively indicating that a protective film forms on the electrode, likely due to PDTC adsorption on the cathodic sites, as $E_{\text {corr }}$ shifts towards more negative values. During the second step, in which $E_{\text {corr }}$ switches towards anodic potentials, $R_{t}$ values still increase suggesting that the protective film continue to form but on the anodic sites. It could be then concluded that PDTC is first adsorbed on the cathodic sites then on the anodic ones to form protective layers on $\mathrm{Cu}$.

To assess the corrosion resistance brought by such formed films, impedance spectra were recorded on $\mathrm{Cu}$ after 24 hours of immersion in the two chloride media, without and with PDTC, and in a large frequency domain $(10 \mathrm{kHz}$ to $10 \mathrm{mHz})$. The obtained data are shown as Bode and Nyquist plots in Fig. 7 and Fig. 8 respectively. Fitted curves represented by crosses (for Nyquist diagrams) or lines (for Bode diagrams) are shown together with experimental data represented by symbols.

Bode plots show that the impedance modulus over the whole frequency range increases markedly when the electrode was left in the solution containing PDTC and demonstrates a good protection performance whatever $\mathrm{Cl}^{-}$ions concentration.

Likewise, Nyquist plots exhibit similar characteristics as convex arcs in the high and middle frequency range, which are depressed capacitive loops involving two time constants though not clearly separated and ascribed respectively to the surface film and the double layer properties $[28,45,46,49]$. Note that the arc diameters increase obviously in presence of the inhibitor indicating the formation of an adsorbed and protective layer. For the blank solutions, the Warburg impedance in a low frequency region is attributed either to transport of dissolved oxygen to the electrode surface [22] or to the transport of chloro-copper complexes such as $\mathrm{CuCl}_{2}{ }^{-}$and $\mathrm{CuCl}_{4}{ }^{2-}$ diffusion to the solution bulk $[49,50]$. In the presence of PDTC, the 
corrosion process is not completely hindered despite the high barrier efficiency of the layer formed on the $\mathrm{Cu}$ surface. Diffusion of corrosive species may happen through this coating but the effect of diffusion limitation may not be dominant in collected data. A Warburg impedance element $\left(Z_{W}\right.$ in $\left.\Omega \mathrm{cm}^{2}\right)$ for the low frequency range, induced by the diffusion of soluble copper species from electrode surface to bulk solution [49], completes the previous circuit. Figure 9 illustrates the model used for parameter regression calculation.

$$
Z_{W}=\frac{\sigma}{\sqrt{j \omega}}
$$

with

$$
\sigma=\frac{R \mathrm{~T}}{z^{2} \mathrm{~F}^{2} D^{1 / 2} C}
$$

where R, $T$ and $\mathrm{F}$ denote the universal gas constant $\left(8.314 \mathrm{~J} \mathrm{~mol}^{-1} \mathrm{~K}^{-1}\right)$, the temperature (K) and the Faraday (96 $485 \mathrm{C} \mathrm{mol}^{-1}$ ), respectively. z, $C$ and $D$ stand for the number of electron involved, the concentration and the diffusion coefficient of the diffusing species through the surface film, respectively. $\omega$ is the angular frequency $\left(\operatorname{rad~s}^{-1}\right)$ defined by the frequency of the AC signal $f: \omega=2 \cdot \pi \cdot f(\mathrm{f}$ in $\mathrm{Hz})$.

Fitted curves are shown together with experimental data in Fig. 7 and Fig. 8 and calculation results are listed in table 2 .

Note that the surface film capacitance value decreases significantly in the presence of PDTC. For instance, in the low concentrated chloride medium $C_{f}$ decreases from 7.44 to about $0.07 \mu \mathrm{F} \mathrm{cm}^{-2}$. This shows that the film formed on $\mathrm{Cu}$ is thick and three-dimensional. In the same way, the film resistance $R_{f}$ increases significantly when the film is formed in PDTC containing solutions, thus this film exhibits a marked barrier efficiency. Moreover, addition of PDTC increases the $R_{t}$ values whatever the chloride concentration of the aggressive solution. This situation indicates that the charge transfer process as well as chloride ions migration 
were inhibited. Besides, the double layer capacitance value decreases significantly in the presence of PDTC, showing that the corroding surface area is smaller. This is consistent with the low values obtained for the coefficient $n_{d}$ indicating the heterogeneity of the electrochemical processes on the active sites. On the other hand, the diffusion through the film becomes difficult, which is in accordance with the high values obtained for the $\sigma$ parameter.

\subsection{Surface analyses}

\subsubsection{SEM and EDS analyses}

Surface observations and the corresponding EDX profile analysis, were performed on the copper electrode after 24 hours immersion in 0.2 or $30 \mathrm{~g} \mathrm{~L}^{-1} \mathrm{NaCl}$ without or with $10 \mathrm{mM}$ PDTC.

An oxides film forms on copper surface in $0.2 \mathrm{~g} \mathrm{~L}^{-1} \mathrm{NaCl}$ as shown in Fig. 10a while a crystalline structure in scales is observed (Fig. 10b) in the presence of PDTC. The formation of an adsorbed PDTC layer on copper is verified by S atom in the EDX analysis (Fig. 10c). In $30 \mathrm{~g} \mathrm{~L}^{-1} \mathrm{NaCl}$ similar results are obtained (Fig. 11). However, the oxide layer formed in inhibitor free solution is thicker in the more concentrated chloride medium (Table 3). Fig. 11a shows, indeed, a more oxidized surface in comparison with that of Fig. 10a. Furthermore, in the presence of PDTC, the SEM image shows a surface appearance essentially covered with an organic layer unlike that observed in Fig. 10a. These observations are consistent with EDX analysis according to which, the layer formed in $0.2 \mathrm{~g} \mathrm{~L}^{-1}$ is composed of oxides and PDTC while no oxide forms in the presence of in $30 \mathrm{~g} \mathrm{~L}^{-1} \mathrm{NaCl}$. Moreover, as shown in the EDX spectra and table 3, on the oxidized surface a significant amount of PDTC molecules is present on the surface, whereas a thin layer of adsorbed PDTC forms on the free oxygen surface. This is in agreement with electrochemical results. 


\subsubsection{XRD analysis}

X-ray diffractograms recorded on copper surface after 24 hours immersion in 0.2 or 30 $\mathrm{g} \mathrm{L}^{-1} \mathrm{NaCl}$, without or with $10 \mathrm{mM}$ PDTC, are shown in Fig. 12. In inhibitor free solution and whatever the chloride content, the X-ray diffraction pattern is typical of those of $\mathrm{Cu}$ and $\mathrm{Cu}_{2} \mathrm{O}$. However, the peaks of $\mathrm{Cu}_{2} \mathrm{O}$ disappear in the case of the PDTC containing solution, in the two chloride media, suggesting the absence of oxides. Only remain $\mathrm{Cu}$ peaks with higher intensity. This is in agreement with electrochemical and EDX / SEM results, which showed that PDTC readily adsorbs on $\mathrm{Cu}$ and prevents oxides formation mainly in the more chloride concentrated medium. The oxide formed in the presence of PDTC in $0.2 \mathrm{~g} \mathrm{~L}^{-1} \mathrm{NaCl}$ is likely not sufficiently crystallized to be detected. Besides, the absence of new peaks in the XRD spectra of the PDTC treated electrodes does not disprove the formation of a three-dimensional PDTC layer but reveals its amorphous character.

\subsubsection{Raman micro-spectroscopy analyses}

Raman micro-spectroscopy characterization of the copper surface after 24 hours exposure to 0.2 or $30 \mathrm{~g} \mathrm{~L}^{-1} \mathrm{NaCl}$ solution, without or with addition of PDTC, was performed in order to investigate the interactions of PDTC with the surface. Fig. 13 shows the spectra collected in addition to those of the pure PDTC molecule in powder state and a $\mathrm{Cu}^{\mathrm{I}}$-PDTC complex formed in solution. Attributions of the main bands are given in table 4 on the basis of literature data [51].

When the film is formed without PDTC, the main feature of the spectrum is a doublet at 500 and $630 \mathrm{~cm}^{-1}$ attributed to $\mathrm{Cu}_{2} \mathrm{O}$ formation [52]. This band still appears in the spectrum of the film formed in $0.1 \mathrm{mM}$ PDTC, but disappears for $10 \mathrm{mM}$ PDTC, which corroborates the above results. Moreover, whatever PDTC concentration, the same main bands are observed in the Raman spectra. The band at $450 \mathrm{~cm}^{-1}$, corresponding to the molecule and assigned to the $\mathrm{S}-\mathrm{C}-\mathrm{S}$ vibration, also appears at the copper surface. This confirms the 
presence of a PDTC layer on the $\mathrm{Cu}$ electrode. In addition, the bands observed at 290 and 330 $\mathrm{cm}^{-1}$ and attributed to $\mathrm{Cu}-\mathrm{S}$ stretching [51], are suggesting that PDTC adsorbs on $\mathrm{Cu}$ by binding with its $\mathrm{S}$ atoms. Furthermore, the similarity between the complex spectrum and those of the surface films shows that the three-dimensional film formed on $\mathrm{Cu}$ surface in the presence of PDTC consist of a Cu' $\mathrm{C}^{\mathrm{I}}$-PDTC complex.

Note that the spectra relative to the surface films in Fig. 13 are obtained in $0.2 \mathrm{~g} \mathrm{~L}^{-1}$ $\mathrm{NaCl}$. Similar spectra were collected in $30 \mathrm{~g} \mathrm{~L}^{-1} \mathrm{NaCl}$.

\subsubsection{XPS analysis}

XPS measurements were performed on Copper electrodes after 24 hours immersion in 0.2 or $30 \mathrm{~g} \mathrm{~L}^{-1} \mathrm{NaCl}$ solution without or with $10 \mathrm{mM}$ PDTC. The spectra obtained are presented in Fig. 14. For both chloride concentrations, quite similar spectra with the same main features were recorded for the blank and $10 \mathrm{mM}$ PDTC.

The survey spectrum for $\mathrm{Cu}$ in presence of PDTC shows peaks representing species containing $\mathrm{C}, \mathrm{N}$ and $\mathrm{S}$ elements indicating that PDTC was adsorbed on the surface. The $\mathrm{C} 1 \mathrm{~s}$ signal could also arise from contamination by adsorbed carbonaceous species as in the case of the blank. Moreover, no peaks for $\mathrm{Cl}$ compounds appear around $200 \mathrm{eV}$ as it could be expected since the samples were treated in chloride media. Similar result was found by Finšgar et al. [53-56] for MBIH-, BTAH-, TRZ ${ }^{-}$and $\mathrm{MBOH}-$ treated $\mathrm{Cu}$ in chloride solutions. Therefore, chloride species are not involved in the PDTC layer which is consistent with a rapid adsorption of PDTC on $\mathrm{Cu}$ surface.

The O1s peak mainly corresponds to the oxidized copper. Traces of oxygen on the surface could also result from atmospheric oxidized species during sample preparation or remaining $\mathrm{H}_{2} \mathrm{O}$ molecules after sample drying [53]. With these remarks, Fig. 15 shows sharper peak of $\mathrm{O} 1 \mathrm{~s}$ for the blank at $530.7 \mathrm{eV}$ indicating the presence of $\mathrm{Cu}_{2} \mathrm{O}[57,58]$ and 
corroborating EDX, DRX and Raman results. According to Roberts [58], the high binding energy shoulder around $533 \mathrm{eV}$ is probably due to small amounts of adsorbed $\mathrm{H}_{2} \mathrm{O}$. As for PDTC treated $\mathrm{Cu}, \mathrm{O} 1 \mathrm{~s}$ peak intensity is extremely low which is in agreement with the above results revealing the lack of oxides in PDTC layer. Moreover, this peak appears at higher binding energies and may be then assigned to adsorbed $\mathrm{H}_{2} \mathrm{O}$ molecules [58].

Fig. 16 shows $\mathrm{Cu} 2 \mathrm{p}$ and $\mathrm{Cu}$ LMM peaks obtained from the films formed without and with PDTC. Clearly, the sharpness of the $\mathrm{Cu} 2 \mathrm{p}$ peaks and the absence of satellites at the high energy side of the $\mathrm{Cu} 2 \mathrm{p}_{3 / 2}$ indicate that the valence state of copper in the surface bond may be

either $\mathrm{Cu}^{0}$ or $\mathrm{Cu}^{\mathrm{I}}[59]$. Moreover, the kinetic energy of the $\mathrm{Cu}$ LMM auger peak is around 916 $\mathrm{eV}$. These are the characteristics of $\mathrm{Cu}^{\mathrm{I}}$ compounds [58-62], indicating that copper in the blank and the inhibitive film is cuprous state. This behaviour is in agreement with the results reported by other workers, where no significant shifts in the binding energy and line-shape variation were detected for $\mathrm{Cu}, \mathrm{Cu}_{2} \mathrm{O}$ and $\mathrm{Cu}_{2} \mathrm{~S}$ [63-67]. Besides, according to Zucchi et al. [66], the shift of $\mathrm{Cu}$ LMM peak to lower kinetic energies for the PDTC treated $\mathrm{Cu}$ can be ascribed to $\mathrm{Cu}^{\mathrm{I}}-\mathrm{S}$ species

Thus, XPS experiments together with Raman results indicate that in chloride media PDTC interacts with $\mathrm{Cu}^{+}$ions through its $\mathrm{S}$ atom to form $\mathrm{Cu}^{\mathrm{I}}$-PDTC complex.

\section{Discussion of Results}

Electrochemical measurements carried out in this study revealed that PDTC reacts strongly with the copper surface thereby decreasing significantly the kinetics of both cathodic and anodic processes regardless of the chloride concentration. In the presence of PDTC, broad passivity plateaus were obtained as shown in Fig. $2 \mathrm{~b}$. In the presence of $0.2 \mathrm{~g} \mathrm{~L}^{-1} \mathrm{NaCl}+$ $10 \mathrm{mM}$ PDTC $\mathrm{Cu}$ remains passive with a current density of $0.1 \mu \mathrm{A} \mathrm{cm}^{-2}$ up to $0.5 \mathrm{~V} / \mathrm{SCE}$. Copper is entirely passive in $10 \mathrm{mM}$ PDTC in a lower $0.2 \mathrm{~g} \mathrm{~L}^{-1} \mathrm{NaCl}$. This clearly shows a 
strong interaction of PDTC with $\mathrm{Cu}$ surface with the most dramatic effects being to that of the anodic reaction although significant slowing of the cathodic reaction also occurs.

To get a better idea of the nature of the electrochemical reaction, EIS measurements not only confirm the role of PDTC in slowing down the electrode kinetics, but also provide insight into the nature of the surface species formed. Specifically, EIS measurements show that PDTC decreases the copper active surface area and raises the charge transfer resistance of the surface film. PDTC adsorbs first on the cathodic sites then on the anodic ones. Moreover, the large increase of the impedance in the capacitive region by more than two orders of magnitude and the exhibition of a nearly ideal capacitance demonstrate that a three dimensional film has formed in the presence of the PDTC.

PDTC or moieties of PDTC incorporate into the surface film as confirmed by SEM and EDX studies. These analyses show that the structure of the layer formed on $\mathrm{Cu}$ in the presence of PDTC differs from that formed with no PDTC. In the blank test solutions, oxides film forms on the copper surface and the surface is more oxidized in $30 \mathrm{~g} \mathrm{~L}^{-1} \mathrm{NaCl}$. However, in the presence of PDTC, a structure with scales is observed. This structure is composed of oxides and PDTC in low $\mathrm{Cl}^{-}$content whereas no oxide and a lower quantity of PDTC forms on copper at higher chloride concentration. On the other hand, EDX analyses confirm the presence of $\mathrm{S}$ in the film while the XRD analyses demonstrates the amorphous nature of this film. Note that EDX would be unable to detect the presence of PDTC N in the film. As presented further on, $\mathrm{N}$ of PDTC was detected by XPS. More information on the exact structure of the inhibiting film is provided by Raman spectroscopy.

At low concentration of PDTC $(0.1 \mathrm{mM})$, the Raman spectrum shows both the characteristic bands of $\mathrm{Cu}_{2} \mathrm{O}$ and a complex (Cu-PDTC) resulting from the interaction of PDTC with the copper surface (Cu-S stretching). On the other hand, the spectrum of the film formed at high concentration (10 mM PDTC) shows only the Cu-PDTC complex bands. This 
corroborates the fact that PDTC prevents oxide formation on the copper surface. Furthermore, PDTC interacts with $\mathrm{Cu}^{\mathrm{I}}$ species as the spectra of the surface film and that of $\mathrm{Cu}^{\mathrm{I}}$-PDTC complex formed in solution were similar. It is entirely possible that a linear metallo-organic polymer comprised of tetrahedral di-aquo $\mathrm{Cu}^{\mathrm{I}}$ bridged at the corners of the tetrahedrum by the bidentate PDTC to the next unit in the form represented by $\left[-\mathrm{Cu}\left(\mathrm{H}_{2} \mathrm{O}\right)_{2}-\mathrm{S}-\mathrm{N}-\mathrm{S}-\right]_{\mathrm{n}}$. Along with the structural information provided by Raman spectroscopy, XPS confirms the presence of the PDTC moiety in the film but also provides evidence on the nature of the $\mathrm{Cu}$ PDTC bond. Specifically XPS spectra contain peaks of the S2p, C1s and N1s which establishes the presence of PDTC molecules on the copper surface. Furthermore, the shape and binding energy of the XPS Cu2p peak indicates that the copper in the surface has a $\mathrm{Cu}^{\mathrm{I}}$ oxidation state. This confirms the formation of $\mathrm{Cu}^{\mathrm{I}}$-PDTC complex on copper surface.

\section{Conclusion}

The results of this study show clearly that PDTC is a good mixed inhibitor for copper corrosion, in neutral chloride media as a result of a strong and fast interaction of PDTC with copper surface to form a stable and protective film.

PDTC inhibits the growth of an oxide layer on the copper while forming a three

dimensional amorphous film composed of a $\mathrm{Cu}^{\mathrm{I}}$-PDTC complex. This complex forms, on copper surface in chloride media, as a result of PDTC interaction with $\mathrm{Cu}$ through its $\mathrm{S}$ atoms.

\section{Acknowledgements}

The University of El Jadida who authorized Pr. W. Qafsaoui to attend the LISE before the end of University year is gratefully acknowledged. 


\section{References}

[1] H. Xu, H. Zhong, S. Wang, Y. Niu, G. Liu, Synthesis of 2-ethyl-2-hexenal oxime and its flotation performance for copper ore, Mineral Engineering, 66-68 (2014) 173180.

[2] K. Rahmouni, H. Takenouti, N. Hajjaji, A. Srhiri, L. Robbiola, Protection of ancient and historic bronzes by triazole derivatives, Electrochimica Acta, 54 (2009) 52065215.

[3] W. Qafsaoui, H. Takenouti, Corrosion protection of 2024-T3 aluminium alloy by electro-polymerized 3-amino 1,2,3-triazole in sulphate solution containing chloride, Corrosion Science 52 (2010) 3667-3676.

[4] C. Blanc, W. Qafsaoui, G. MacCarthy, G. Mankowski, Inhibition of the pitting corrosion of 2024 alloy by 1,2,3-Benzotriazole , Corrosion and Corrosion Protection, in: J.D. Sinclair, R. Frankenthal, E. Kalman, W. Plieth, (Eds.), Proceedings of 200th Electrochemical Society Meeting, SanFrancisco (USA), September 2001, 'Corrosion and Corrosion Protection' PV 200122 (2003) 459-466.

[5] W. Qafsaoui, H. Huet, H. Takenouti, Analysis of the inhibitive effect of BTAH on localized corrosion of Al 2024 from electrochemical noise measurements, Journal of the Electrochemical Society 156 (2) (2009) C67-C74.

[6] M.A. Páez, J.H. Zagal, O. Bustos, M.J. Aguirre, P. Skeldon, G.E. Thompson, Effect of benzotriazole on the efficiency of anodizing of Al-Cu alloys, Electrochimica Acta, 42 (1997) 3453-3459.

[7] D. Zhu, W.J. Van Ooij, Corrosion protection of AA 2024-T3 by bis-[3(triethoxysilyl)propyl]tetrasulfide in sodiumchloride solution. Part 2: mechanism for corrosion protection, Corrosion Science, 45 (2003) 2177-2197. 
[8] M. Iannuzzi, G.S. Frankel, Mechanisms of corrosion inhibition of AA2024-T3 by vanadates, Corrosion Science, 49 (2007) 2371-2391.

[9] Y. Hong, D. K. Devarapalli, D. Roy, S.V. Babu, Synergistic roles of dodecyl sulfate and benzotriazole in enhancing the efficiency of CMP of copper, Journal of the Electrochemical Society, 154 (6) (2007) H444-H453.

[10] I. Dugdale, J.B. Cotton, An electrochemical investigation on the prevention of staining of copper by benzotriazole, Corrosion Science, 3 (1963) 69-74.

[11] R. Walker, Triazole, Benzotriazole and Naphthotriazole as Corrosion Inhibitors for Copper, Corrosion, 31 (3) (1975) 97-100.

[12] M. Finšgar, I. Milošev, Inhibition of copper corrosion by 1,2,3-benzotriazole: A review, Corrosion Science, 52 (9) (2010) 2737-2749.

[13] M.M. Antonijevic, M.B. Petrovic, Copper corrosion inhibitors. A review, International Journal of Electrochemical Science, 3 (2008) 1-28.

[14] O. Blajiev, A. Hubin, Inhibition of copper corrosion in chloride solutions by aminomercapto-thiadiazol and methyl-mercapto-thiadiazol: an impedance spectroscopy and a quantum-chemical investigation, Electrochimica Acta, 49 (2004) 2761-2770.

[15] M. Finšgar, 2-Mercaptobenzimidazole as a copper corrosion inhibitor: Part II. Surface analysis using X-ray photoelectron spectroscopy, Corrosion Science, 72 (2013) 90-98.

[16] M. Finšgar, D. Kek Merl, An electrochemical, long-term immersion, and XPS study of 2-mercaptobenzothiazole as a copper corrosion inhibitor in chloride solution, Corrosion Science, 83 (2014) 164-175.

[17] M. Finšgar, D. Kek Merl, 2-Mercaptobenzoxazole as a copper corrosion inhibitor in chloride solution: Electrochemistry, 3D-profilometry, and XPS surface analysis, Corrosion Science, 80 (2014) 82-95. 
[18] M. Ohsawa, W. Suëtaka, Spectro-electrochemical studies of the corrosion inhibition of copper by mercaptobenzothiazole, Corrosion Science, 19 (1979) 709-722.

[19] A.B. Patel, N.K. Patel, J.C. Vora, ,2-mercaptothiazoline as corrosion inhibitor for copper in acidic media, Corrosion Science, 14 (1974) 233-237.

[20] G. Tansuğ, T. Tüken, E.S. Giray, G. Fındıkkıran, G. Sığırcık, O. Demirkol, M. Erbil, A new corrosion inhibitor for copper protection, Corrosion Science, 84 (2014) 21-29.

[21] C.W. Yan, H.C. Lin, C.N. Cao, Investigation of inhibition of 2-mercaptobenzoxazole for copper corrosion, Electrochimica Acta, 45 (2000) 2815-2821.

[22] B.V. Appa Rao, Md. Yakub Iqbal, B. Sreedhar, Self-assembled monolayer of 2(octadecylthio) benzothiazole for corrosion protection of copper, Corrosion Science, 51 (2009) 1441-1452.

[23] M. Behpour, N. Mohammadi, Investigation of inhibition properties of aromatic thiol self-assembled monolayer for corrosion protection. Corrosion Science, 65 (2012) 331339.

[24] W. Chen, S. Hong, H.B. Li, H.Q. Luo, M. Li, N.B. Li, Protection of copper corrosion in $0.5 \mathrm{M} \mathrm{NaCl}$ solution by modification of 5-mercapto-3-phenyl-1,3,4-thiadiazole-2thione potassium self-assembled monolayer, Corrosion Science, 61 (2012) 53-62.

[25] S.S. Pathak, V. Yegnaraman, J. Mathiyrasu, M. Maji, A.S. Khanna, Corrosion studies of organicdithiol/monothiol derived self assembled monolayer on copper substrate towards corrosion protection in $0.5 \mathrm{M} \mathrm{NaCl}$, Indian Journal of Chemical Technology, $14(2007) 5-15$.

[26] T.T. Qin, J. Li, H.Q. Luo, M. Li, N.B. Li, Corrosion inhibition of copper by 2,5dimercapto-1,3,4-thiadiazole monolayer in acidic solution, Corrosion Science, 53 (2011) 1072-1078. 
[27] M. Guzman, R. Lara, L. Vera, Determination of Corrosion and Adsorption Parameters of 1, 3, 4-thiadiazole-2, 5-dithiol on ASTM A-890-1B Stainless Steel in 3.5\% NaCl Solution, International Journal of Electrochemical Science, 8 (2013) 12051-12061.

[28] W. Qafsaoui, M.W. Kendig, H. Perrot, H. Takenouti, Coupling of electrochemical techniques to study copper corrosion inhibition in $0.5 \mathrm{~mol} \mathrm{~L}^{-1}$ by 1-pyrrolidine dithiocarbamate, Electrochemica Acta, 87 (2013) 348-360.

[29] W. Qafsaoui, M.W. Kendig, H. Perrot, H. Takenouti, Corrosion Inhibition of Copper by Selected Thiol Compounds, ECS Transactions, 13 (27) (2008) 123-132.

[30] M. Kendig, M. Hon, J. Sinko, Inhibition of oxygen reduction on copper in neutral sodium chloride, corrosion inhibition - non ferrous metals, ECS Transactions 1 (9) (2006) 119-129.

[31] M. Kendig, M. Hon, A hydrotalcite-like pigment containing an organic anion corrosion inhibitor corrosion, passivation, and anodic films, Electrochemical and Solid State Letters 8 (2005) B10-B11.

[32] M. Kendig, C. Yan, Critical concentrations for selected oxygen reduction reaction inhibitors corrosion, passivation, and anodic films, Journal of the Electrochemical Society 151 (2004) B679-B682.

[33] M. Kendig, P. Kinlen, Demonstration of Galvanically Stimulated Release of a Corrosion Inhibitor. Basis for "Smart" Corrosion Inhibiting Materials, Journal of the Electrochemical Society, 154 (4) (2007) C195-C201.

[34] G. Williams, A.J. Coleman, H.N. McMurray, Inhibition of Aluminium Alloy AA2024-T3 pitting corrosion by copper complexing compounds, Electrochimica Acta, 55 (2010) 5947-5958. 
[35] M. M. Singh, R. B. Rastogi, B.N. Upadhyay, Inhibition of Copper Corrosion in Aqueous Sodium Chloride Solution by Various Forms of the Piperidine Moiety, Corrosion, 50 (8) (1994) 620-625.

[36] S. Kanchi, P. Singh, K. Bisetty, Dithiocarbamates as hazardous remediation agent: A critical review on progress in environmental chemistry for inorganic species studies of 20th century, Arabian Journal of Chemistry, 7 (2014) 11-25.

[37] A.E. Al-Rawajfeh, E.M. Al-Shamaileh, Inhibition of corrosion in steel water pipes by ammonium pyrrolidine dithiocarbamate (APDTC), Desalination, 206 (2007) 169-178.

[38] S .Cuzzocrea, P.K. Chatterjee, E. Mazzon, L. Dugo, I. Serraino, D. Britti, G. Mazzulo, A.P. Caputi, C. Thiermermann, Pyrrolidine dithiocarbamate attenuates the development of acute and chronic inflammation, British Journal of Pharmacology, 135 (2002) 496-510.

[39] J. Chen, C. Du, J. Kang, J. Wang, $\mathrm{Cu}^{2+}$ is required for pyrrolidine dithiocarbamate to inhibit histone acetylation and induce human leukemia cell apoptosis, ChemicoBiological Interactions, 171 (2008) 26-36 .

[40] C. Deslouis, B. Tribollet, G. Mengoli, M.M. Musiani, Electrochemical behavior of copper in neutral aerated chloride solution. I. Steady-state investigation, Journal of Applied Electrochemistry, 18 (1988) 374-383.

[41] H.P. Lee, K. Nobe, Kinetics and mechanisms of $\mathrm{Cu}$ electrodissolution in chloride media, Journal of the Electrochemical Society, 133 (1986) 2035-2043.

[42] G. Kear, B.D. Barker, F.C. Walsh, Electrochemical corrosion of unalloyed copper in chloride media-a critical review, Corrosion Science, 46 (2004) 109-135.

[43] A. Shaban, E. Kálmán, J. Telegdi, An investigation of copper corrosion inhibition in chloride solutions by benzo-hydroxamic acids, Electrochimica Acta, 43 (1998) 159163. 
[44] M. Stern, A.L. Geary, Electrochemical polarization: I. A Theoretical analysis of the shape of polarization curves, Journal of the Electrochemical Society, 104 (1957) 5663.

[45] H. Otmacic Curkovic, E. Stupnisek-Lisac, H. Takenouti, The influence of $\mathrm{pH}$ value on the efficiency of imidazole based corrosion inhibitors of copper, Corrosion Science 52 (2010) 398-405.

[46] K. Marušić, H. Otmačić Ćurković, S, Horvat-Kurbegovic, H. Takenouti, E. StupnišekLisac, Comparative studies of chemical and electrochemical preparation of artificial bronze patinas and their protection by corrosion inhibitor, Electrochimica Acta, 54 (2009) 7106-7113.

[47] E. Barsoukov, J.R. Macdonald, Impedance spectroscopy, Theory, experiment, and applications, John Wiley and Sons, New York , NY, (2005) 16-20 .

[48] K.S. Cole, R.H. Cole, Dispersion and absorption in dielectrics - I Alternating current characteristics. Journal of Chemical Physics 9 (1941) 341-351.

[49] O.E. Barcia, O.R. Mattos, N. Pébère, B. Tribollet, Mass-transport study for the electrodissolution of copper in $1 \mathrm{M}$ hydrochloric acid solution by impedance, Journal of the Electrochemical Society, 140 (1993) 2825-2832.

[50] S. Hong, W. Chen, H.Q. Luo, N.B. Li, Inhibition effect of 4-amino-antipyrine on the corrosion of copper in $3 \mathrm{wt} \% \mathrm{NaCl}$ solution, Corrosion Science, 57 (2012) 270-278.

[51] Q.Q. Liao, Z.W. Yue, D. Yang, Z.H. Wang, Z.H. Li, H.H. Ge, Y.J. Li, Self-assembled monolayer of ammonium pyrrolidine dithiocarbamate on copper detected using electrochemical methods, surface enhanced Raman scattering and quantum chemistry calculations, Thin Solid Films, 519 (2011) 6492-6498.

[52] M.C. Bernard, S. Joiret, Understanding corrosion of ancient metals for the conservation of cultural heritage, Electrochimica Acta, 54 (2009) 5199-5205. 
[53] M. Finšgar, 2-Mercaptobenzimidazole as a copper corrosion inhibitor: Part II. Surface analysis using X-ray photoelectron spectroscopy, Corrosion Science, 72 (2013) 90-98.

[54] M. Finšgar, EQCM and XPS analysis of 1,2,4-triazole and 3-amino-1,2,4-triazole as copper corrosion inhibitors in chloride solution, Corrosion Science, 77 (2013) 350359.

[55] M. Finšgar, J. Kovač, I. Milošev, Surface analysis of 1-hydroxybenzotriazole and benzoltriazole adsorbed on $\mathrm{Cu}$ by $\mathrm{X}$-ray photoelectron spectroscopy, Journal of the Electrochemical Society, 157 (2010) C52-C60.

[56] M. Finšgar, D.K. Merl, 2-Mercaptobenzoxazole as a copper corrosion inhibitor in chloride solution: Electrochemistry, 3D-profilometry, and XPS surface analysis, Corrosion Science, 80 (2014) 82-95.

[57] B. Millet, C. Fiaud, C. Hinnen, E.M.M. Sutter, A correlation between electrochemical behaviour, composition and semiconducting properties of naturally grown oxide films on copper, Corrosion Science, 37 (1995) 1903-1918.

[58] R.F. Roberts, X-Ray photoelectron spectroscopic characterization of copper oxide surfaces treated with benzotriazole, Journal of Electron Spectroscopy and related phenomena, 4 (1974) 273-291.

[59] Handbook of X-ray Photoelectron Spectroscopy, Ed. G.E. Muilenberg, Perkin-Elmer Corporation, Eden Prairie, Minnesota (1979).

[60] T. Novakov, R. Prins, Band structure and the shakeup photoelectron spectra of copper and nickel halides and oxides, Solid State Communications, 9 (1971) 1975.

[61] G. Panzner, B. Egert, H.P. Schmidt, The stability of $\mathrm{CuO}$ and $\mathrm{Cu}_{2} \mathrm{O}$ surfaces during argon sputtering studied by XPS and AES, Surface Science, 151 (1985) 400-408.

[62] G. Schön, ESCA studies of $\mathrm{Cu}, \mathrm{Cu}_{2} \mathrm{O}$ and $\mathrm{CuO}$, Surface Science, 35 (1973) 96-108. 
[63] P.E. Larson, $\mathrm{X}$-Ray induced photoelectron and Auger spectra of $\mathrm{Cu}, \mathrm{CuO}, \mathrm{Cu}_{2} \mathrm{O}$ and $\mathrm{Cu}_{2} \mathrm{~S}$ thin films, Journal of Electron Spectroscopy and related phenomena, 4 (1974)213-218.

[64] I. Nakai, Y. Sugitani, K. Nagashima, X-Ray photoelectron spectroscopic study of copper minerals, Journal of Inorganic and Nuclear Chemistry, 40 (1978) 789-791.

[65] L.P. Kazansky, I.A. Selyaninov, Yu.I. Kuznetsov, Adsorption of 2mercaptobenzothiazole on copper surface from phosphate solutions, Applied Surface Science, 258 (2012) 6807-6813.

[66] F. Zucchi, A. Frignani, V. Grassi, G. Trabanelli, M. DalColle, The formation of a protective layer of 3-mercapto-propyl-trimethoxy-silane on copper, Corrosion Science, 49 (2007) 1570-1583.

[67] D. Chadwick, T. Hashemi, Electron spectroscopy of corrosion inhibitors: surface films formed by 2-mercaptobenzothiazole and 2-mercaptobenzimidazole on copper, Surface Science, 89 (1979) 649-659. 
Tables

Table 1: Corrosion parameters of copper obtained from polarization curves

in 0.2 and $30 \mathrm{~g} \mathrm{~L}^{-1} \mathrm{NaCl}$ without and with $10 \mathrm{mM}$ PDTC

\begin{tabular}{|c|c|c|c|c|}
\hline Parameters & $0.2 \mathrm{~g} \mathrm{~L}^{-1} \mathrm{NaCl}$ & $\begin{array}{l}0.2 \mathrm{~g} \mathrm{~L}^{-1} \mathrm{NaCl} \\
+10 \mathrm{mMPDTC}\end{array}$ & $30 \mathrm{~g} \mathrm{~L}^{-1} \mathrm{NaCl}$ & $\begin{array}{l}30 \mathrm{~g} \mathrm{~L}^{-1} \mathrm{NaCl} \\
+10 \mathrm{mMPDTC}\end{array}$ \\
\hline$E_{\text {corr }}(\mathrm{V} / \mathrm{SCE})$ & -0.120 & -0.296 & -0.224 & -0.203 \\
\hline$j_{\text {corr }}\left(\mathrm{nA} / \mathrm{cm}^{2}\right)$ & 195.1 & 1.82 & 2073 & 83.68 \\
\hline$b_{a}\left(\mathrm{~V} \mathrm{dec}{ }^{-1}\right)$ & 0.057 & 0.512 & 0.058 & 0.277 \\
\hline$b_{c}\left(\mathrm{~V} \mathrm{dec}^{-1}\right)$ & -0.205 & -0.208 & -0.170 & -0.324 \\
\hline$R_{p}\left(\mathrm{k} \Omega . \mathrm{cm}^{2}\right)$ & 99.26 & $35.30 \times 10^{3}$ & 9.06 & 774.9 \\
\hline$E \%$ & - & 99.06 & - & 95.96 \\
\hline
\end{tabular}


Table 2: Electrochemical impedance parameters for copper in 0.2 and $30 \mathrm{~g} \mathrm{~L}^{-1} \mathrm{NaCl}$ without and with $10 \mathrm{mM}$ PDTC

\begin{tabular}{|c|c|c|c|c|c|c|c|c|}
\hline Solutions & $\begin{array}{c}R_{S} \\
\left(\Omega \mathrm{cm}^{2}\right)\end{array}$ & $\begin{array}{c}C_{f} \\
\left(\mu \mathrm{F} \mathrm{cm}^{-2}\right)\end{array}$ & $n_{f}$ & $\begin{array}{c}R_{f} \\
\left(\mathrm{k} \Omega \mathrm{cm}^{2}\right)\end{array}$ & $\begin{array}{c}C_{d} \\
\left(\mu \mathrm{F} \mathrm{cm}^{-2)}\right.\end{array}$ & $n_{d}$ & $\begin{array}{c}R_{t} \\
\left(\mathrm{k} \Omega \mathrm{cm}^{2}\right)\end{array}$ & $\begin{array}{c}\sigma \\
\left(\Omega \mathrm{s}^{-1 / 2}\right)\end{array}$ \\
\hline $0.2 \mathrm{~g} \mathrm{~L}^{-1} \mathrm{NaCl}$ & 145 & 7.44 & 0.76 & 23.1 & 22.36 & 0.89 & 5.65 & 1714 \\
\hline $30 \mathrm{~g} \mathrm{~L}^{-1} \mathrm{NaCl}$ & 1.51 & 168.2 & 0.51 & 0.018 & 133.3 & 0.91 & 5.43 & 509.5 \\
\hline $\begin{aligned} & 0.2 \mathrm{~g} \mathrm{~L}^{-1} \mathrm{NaCl} \\
+ & 10 \mathrm{mM} \text { PDTC }\end{aligned}$ & 129 & 0.069 & 0.97 & $3.68 \times 10^{4}$ & 0.0368 & 0.35 & $7.88 \times 10^{4}$ & $69 \times 10^{4}$ \\
\hline $\begin{aligned} & 30 \mathrm{~g} \mathrm{~L}^{-1} \mathrm{NaCl} \\
+ & 10 \mathrm{mM} \text { PDTC }\end{aligned}$ & 0.59 & 0.058 & 0.96 & $1.4 \times 10^{3}$ & 0.167 & 0.37 & $3.4 \times 10^{3}$ & $6.4 \times 10^{4}$ \\
\hline
\end{tabular}


Table 3: EDX analysis of copper surface after 24 hours immersion in 0.2 and $30 \mathrm{~g} \mathrm{~L}^{-1} \mathrm{NaCl}$ without and with $10 \mathrm{mM}$ PDTC

\begin{tabular}{ccccc}
\hline $\begin{array}{c}\text { Element } \\
\text { at } \%\end{array}$ & $0.2 \mathrm{~g} \mathrm{~L}^{-1} \mathrm{NaCl}$ & $\begin{array}{c}0.2 \mathrm{~g} \mathrm{~L}^{-1} \mathrm{NaCl} \\
+10 \mathrm{mMPDTC}\end{array}$ & $30 \mathrm{~g} \mathrm{~L}^{-1} \mathrm{NaCl}$ & $\begin{array}{c}30 \mathrm{~g} \mathrm{~L}^{-1} \mathrm{NaCl} \\
+10 \mathrm{mMPDTC}\end{array}$ \\
\hline $\mathrm{Cu}$ & 91.11 & 18.96 & 76.97 & 92.31 \\
$\mathrm{O}$ & 8.89 & 8.81 & 22.66 & - \\
$\mathrm{S}$ & - & 72.23 & - & 7.69 \\
\hline
\end{tabular}


Table 4: Vibrational wavenumbers and assignments for PDTC molecule, $\mathrm{Cu}^{\mathrm{I}}$-PDTC complex and surface film

\begin{tabular}{|c|c|c|c|}
\hline \multicolumn{4}{|c|}{ Raman wavenumber $\left(\mathrm{cm}^{-1}\right)$} \\
\hline Surface film & $\mathrm{Cu}^{\mathrm{I}}$-PDTC complex & PDTC molecule & Assignment \\
\hline 225 & 225 & & \\
\hline 285 & 288 & & $\mathrm{Cu}-\mathrm{S}$ stretching \\
\hline & & 300 & $\begin{array}{l}\mathrm{N}-\mathrm{C}-\mathrm{S} \text { in plane } \\
\text { bending }\end{array}$ \\
\hline 330 & 336 & & $\mathrm{Cu}-\mathrm{S}$ stretching \\
\hline 448 & 459 & 445 & S-C-S stretching \\
\hline 595 & 600 & 571 & $\begin{array}{l}\text { Ring in plane } \\
\text { bending }\end{array}$ \\
\hline 706 & 700 & 700 & $\begin{array}{c}\text { S-C-S anti } \\
\text { symmetric stretching }\end{array}$ \\
\hline
\end{tabular}




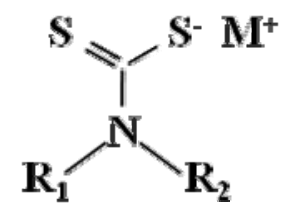

(a)

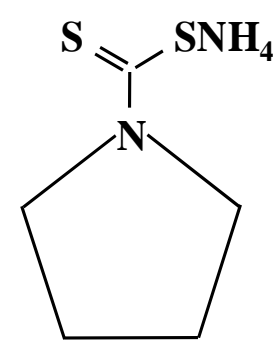

(b)

Figure 1: Structures of dialkyl dithiocarbamate (a) and ammonium pyrrolidine dithiocarbamate (b). 

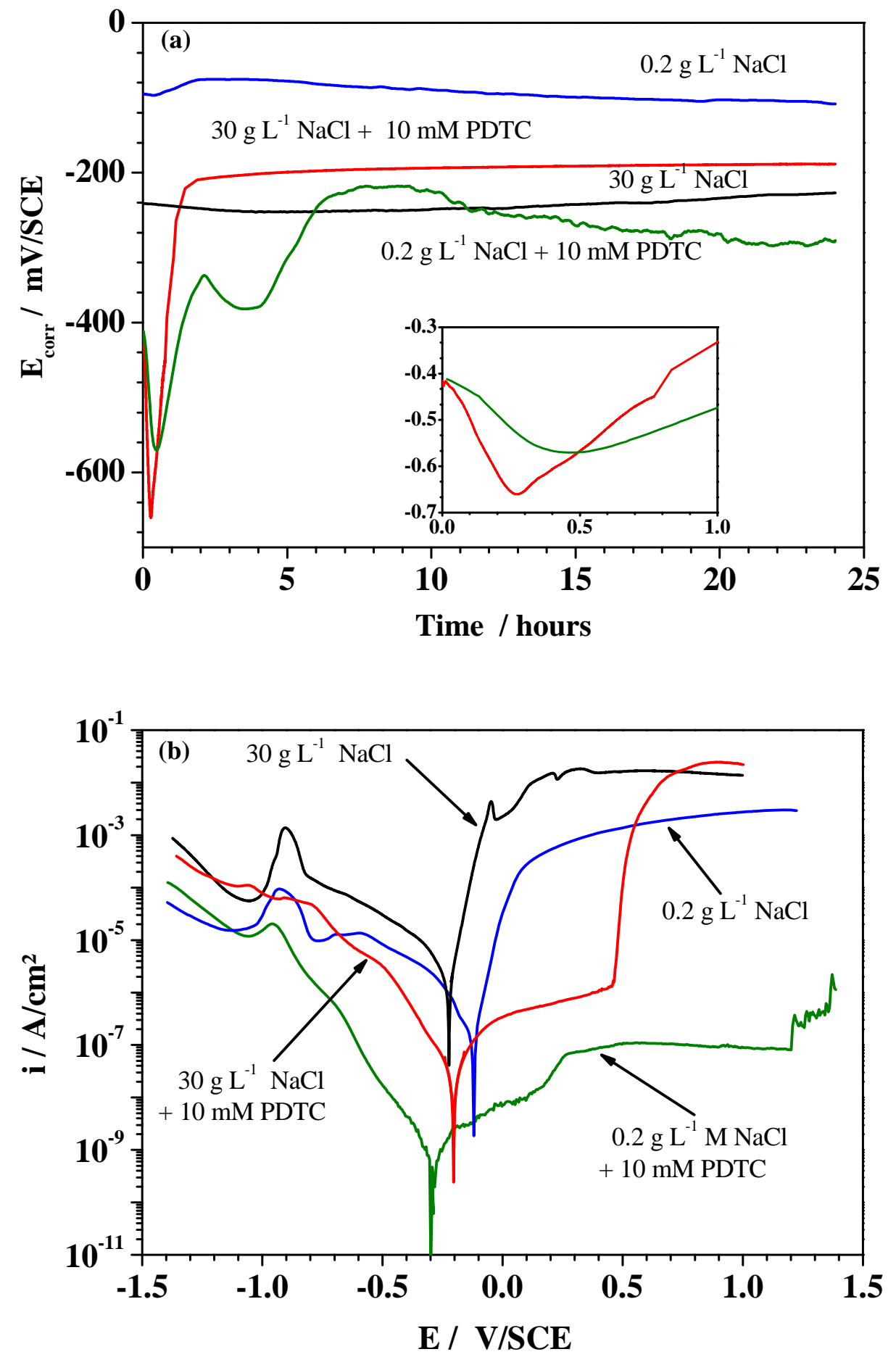

Figure 2: Open circuit potential plots (a) for copper during $24 \mathrm{~h}$ exposure time in 0.2 or 30 $\mathrm{g} \mathrm{L}^{-1} \mathrm{NaCl}$ without or with $10 \mathrm{mM}$ PDTC and polarization plots (b) after exposure; stationary electrode at $20^{\circ} \mathrm{C}$. 


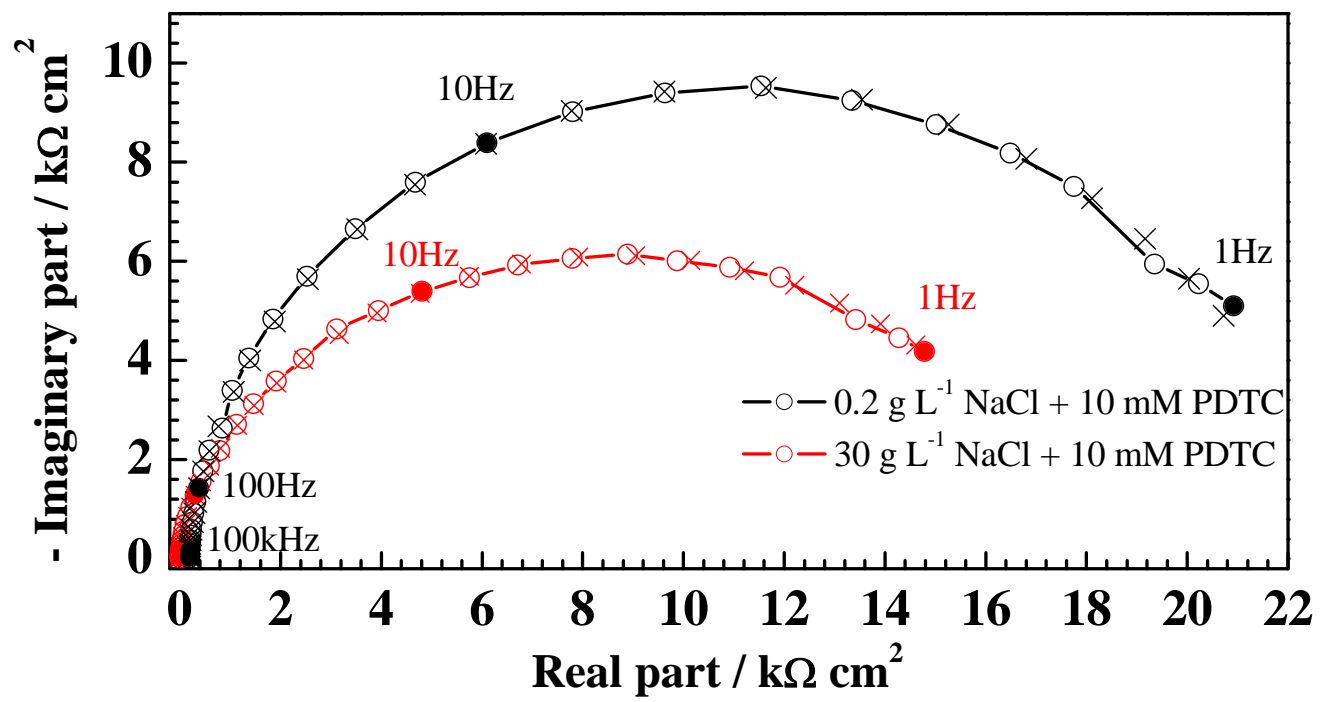

Figure 3: Nyquist diagrams of copper after 100 seconds exposure time in $0.2 \mathrm{~g} \mathrm{~L}^{-1}+10 \mathrm{mM}$ PDTC or $30 \mathrm{~g} \mathrm{~L}^{-1}+10 \mathrm{mM}$ PDTC; stationary electrode at $20^{\circ} \mathrm{C}$.

Symbols $=$ experimental data; and crosses $=$ calculated data . 


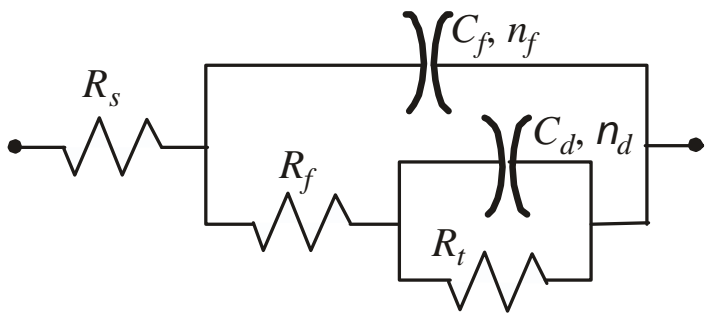

Figure 4: Electrical equivalent circuit to reproduce experimental impedance spectra for $\mathrm{Cu}$ electrode in 0.2 or $30 \mathrm{~g} \mathrm{~L}^{-1} \mathrm{NaCl}$ without or with $10 \mathrm{mM}$ PDTC for high and medium frequencies. 

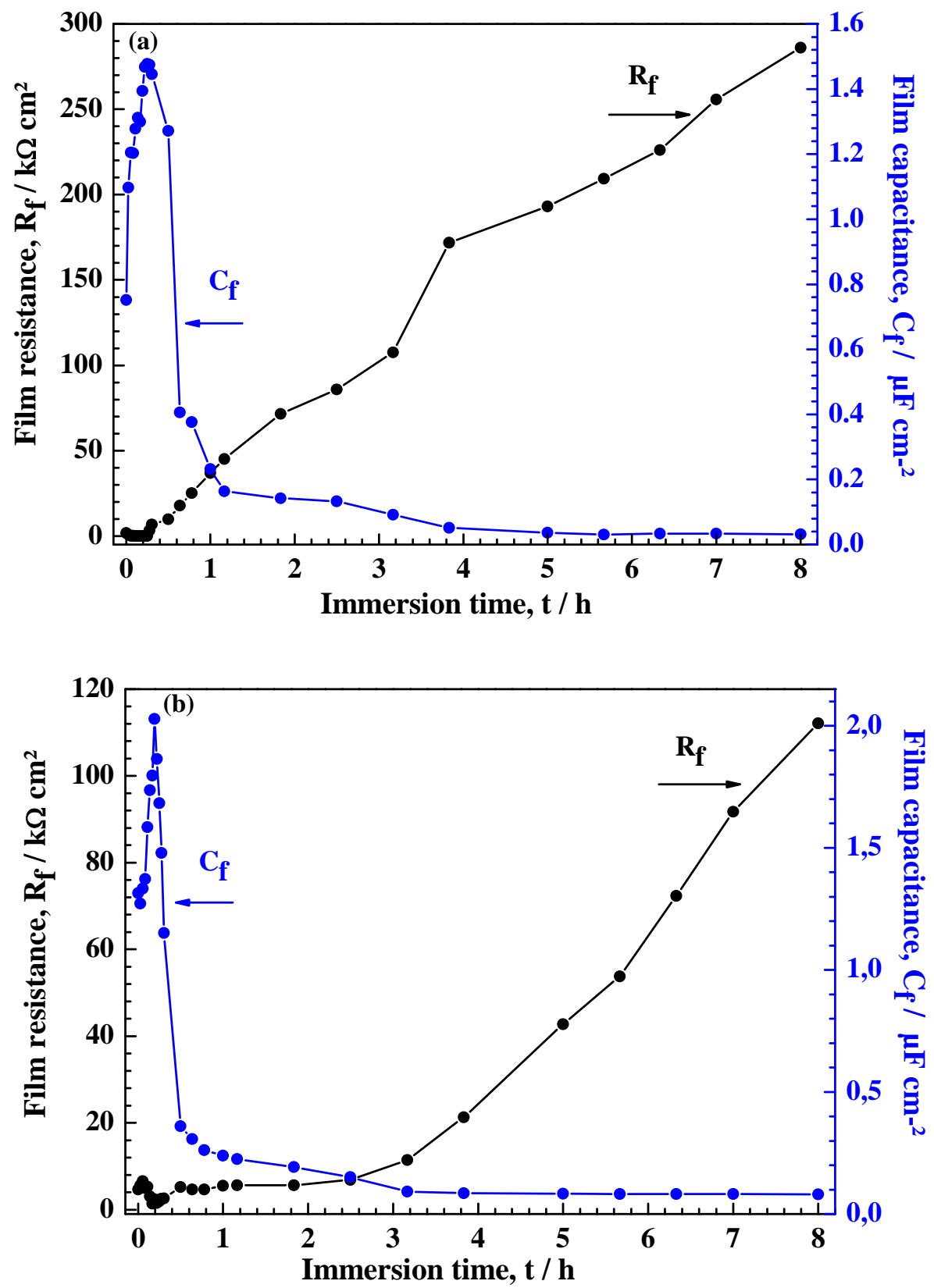

Figure 5: $\mathrm{R}_{\mathrm{f}}$ and $\mathrm{C}_{\mathrm{f}}$ change as a function of immersion period for $\mathrm{Cu} / 0.2 \mathrm{~g} \mathrm{~L}^{-1} \mathrm{NaCl}+10$ mM PDTC (a) and Cu / $30 \mathrm{~g} \mathrm{~L}^{-1} \mathrm{NaCl}+10 \mathrm{mM}$ PDTC (b); stationary electrode at $20^{\circ} \mathrm{C}$. 

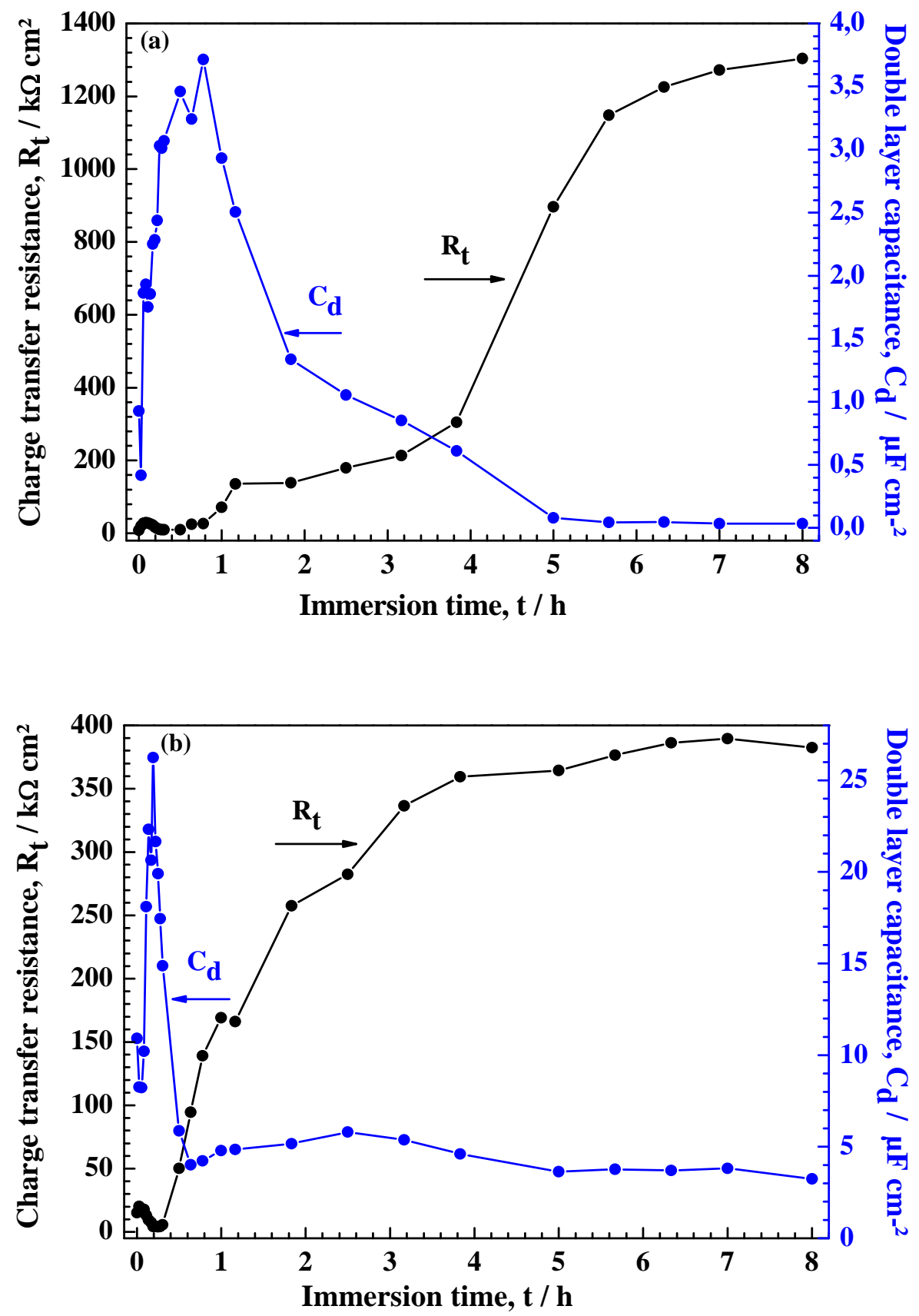

Figure 6: $R_{t}$ and $C_{d}$ change as a function of immersion period for $\mathrm{Cu} / 0.2 \mathrm{~g} \mathrm{~L}^{-1} \mathrm{NaCl}+10$ mM PDTC (a) and $\mathrm{Cu} / 30 \mathrm{~g} \mathrm{~L}^{-1} \mathrm{NaCl}+10 \mathrm{mM}$ PDTC (b); stationary electrode at $20^{\circ} \mathrm{C}$. 

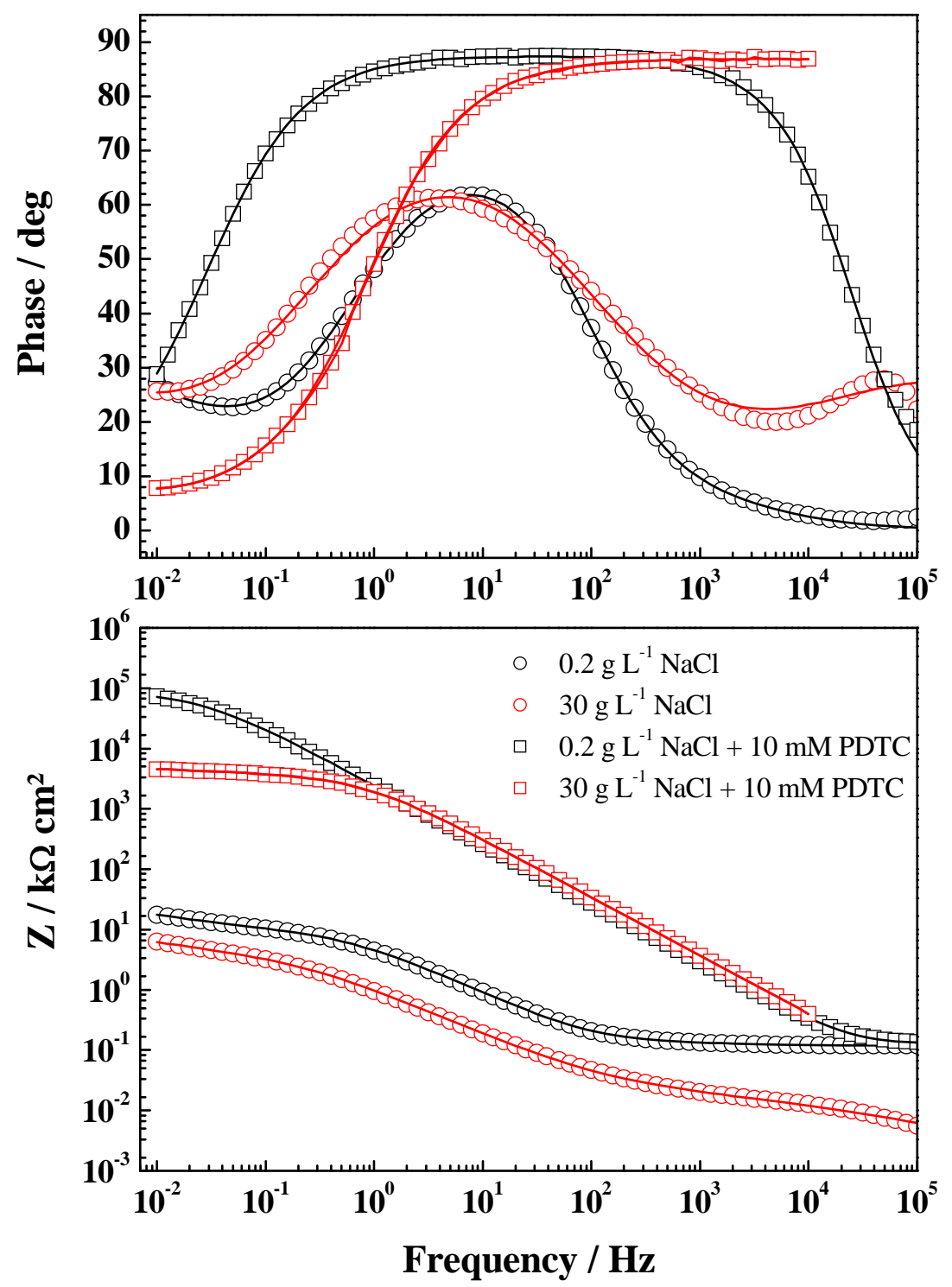

Figure 7: Bode diagrams of copper after $24 \mathrm{~h}$ exposure time in 0.2 or $30 \mathrm{~g} \mathrm{~L}^{-1}$ without or with $10 \mathrm{mM}$ PDTC; stationary electrode at $20^{\circ} \mathrm{C}$.

Symbols $=$ experimental data; and lines $=$ calculated data . 

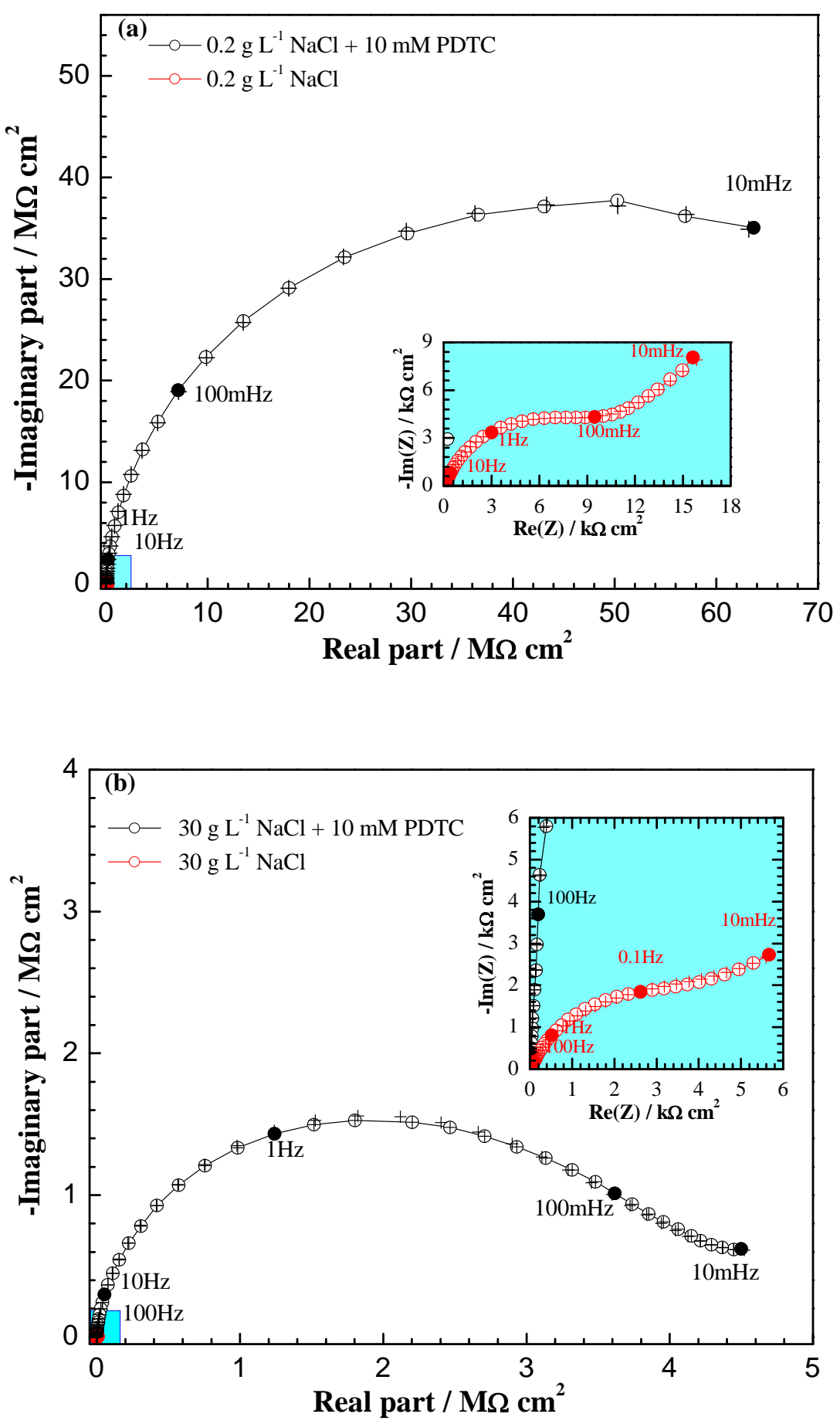

Figure 8: Nyquist diagrams of copper after $24 \mathrm{~h}$ exposure time in $0.2 \mathrm{~g} \mathrm{~L}^{-1}$ (a) or $30 \mathrm{~g} \mathrm{~L}^{-1}$ (b) without or with $10 \mathrm{mM}$ PDTC; stationary electrode at $20^{\circ} \mathrm{C}$.

Symbols $=$ experimental data; and crosses $=$ calculated data. 


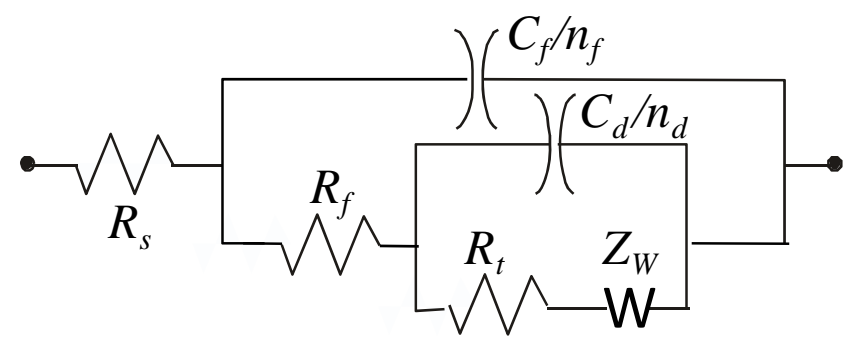

Figure 9: Electrical equivalent circuit to reproduce experimental impedance spectra for $\mathrm{Cu}$ electrode in $\mathrm{NaCl}$ solution without or with PDTC. 

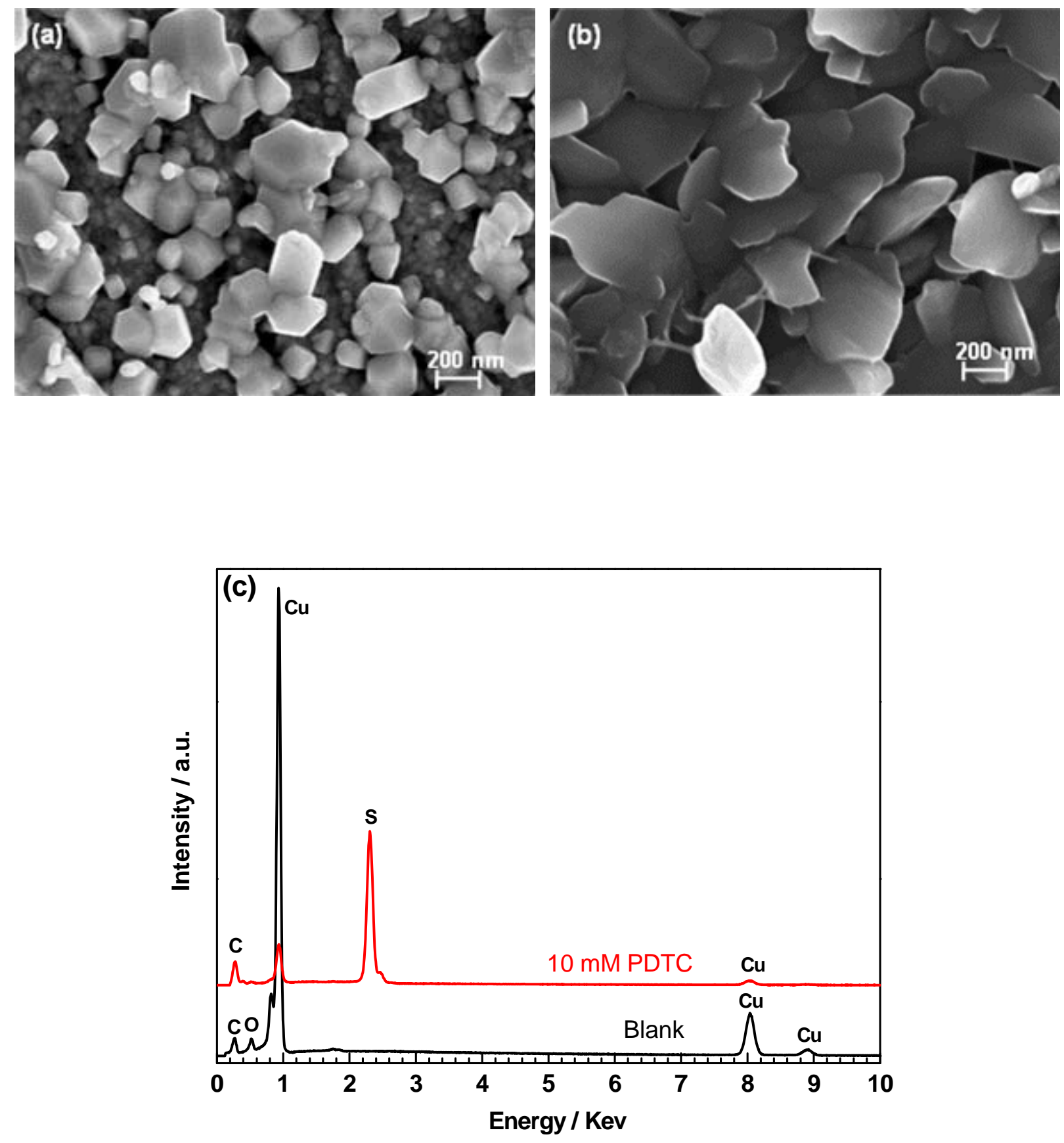

Figure 10: SEM images of copper surface after $24 \mathrm{~h}$ immersion time in $0.2 \mathrm{~g} \mathrm{~L}^{-1} \mathrm{NaCl}$ without (a) and with $10 \mathrm{mM}$ PDTC (b) and the corresponding EDX analysis (c). 

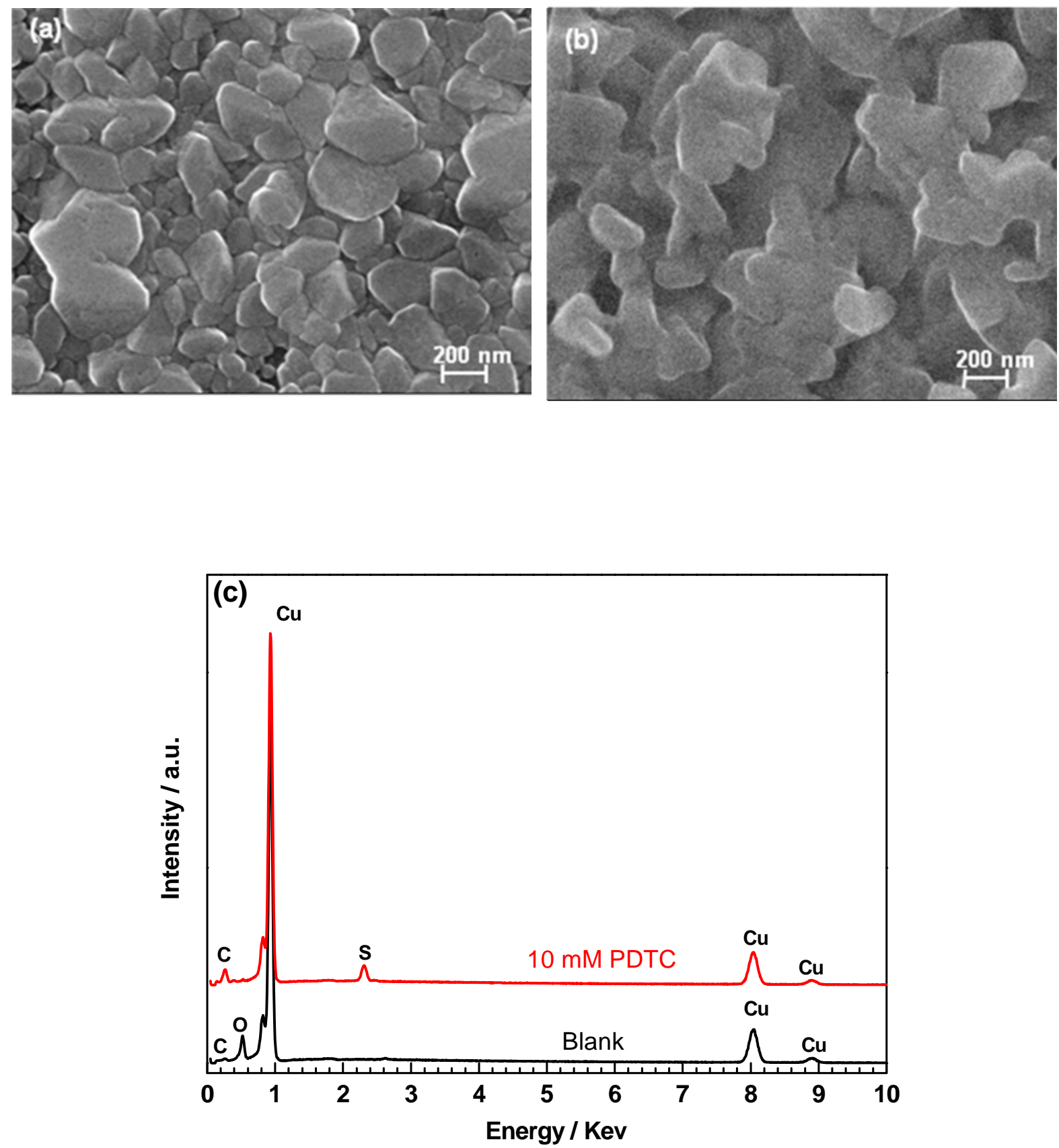

Figure 11: SEM images of copper surface after $24 \mathrm{~h}$ immersion time in $30 \mathrm{~g} \mathrm{~L}^{-1} \mathrm{NaCl}$ without (a) and with 10 mM PDTC (b) and the corresponding EDX analysis (c). 


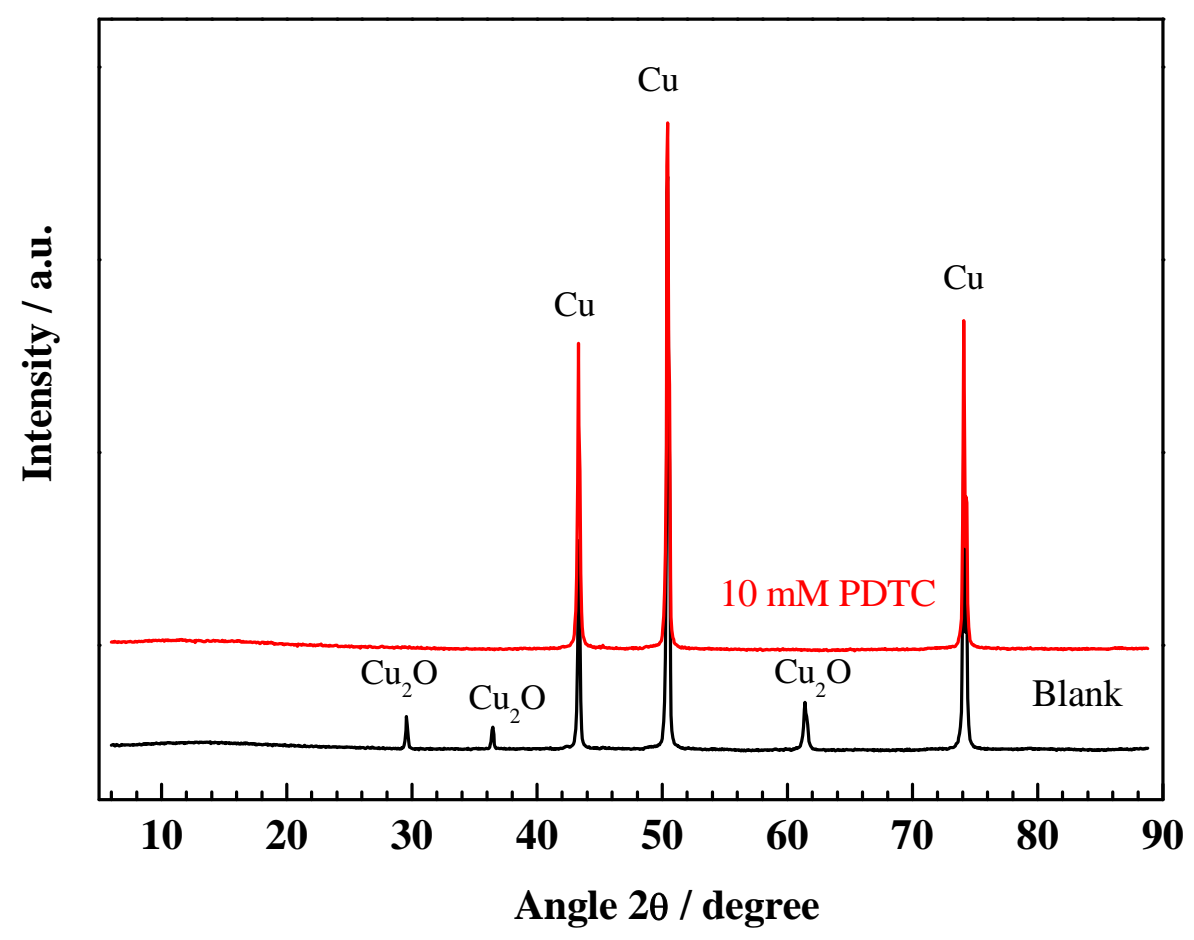

Figure 12: XRD pattern recorded on the copper surface after $24 \mathrm{~h}$ immersion in 0.2 or $30 \mathrm{~g} \mathrm{~L}^{-1}$ $\mathrm{NaCl}$ without or with $10 \mathrm{mM}$ PDTC. 


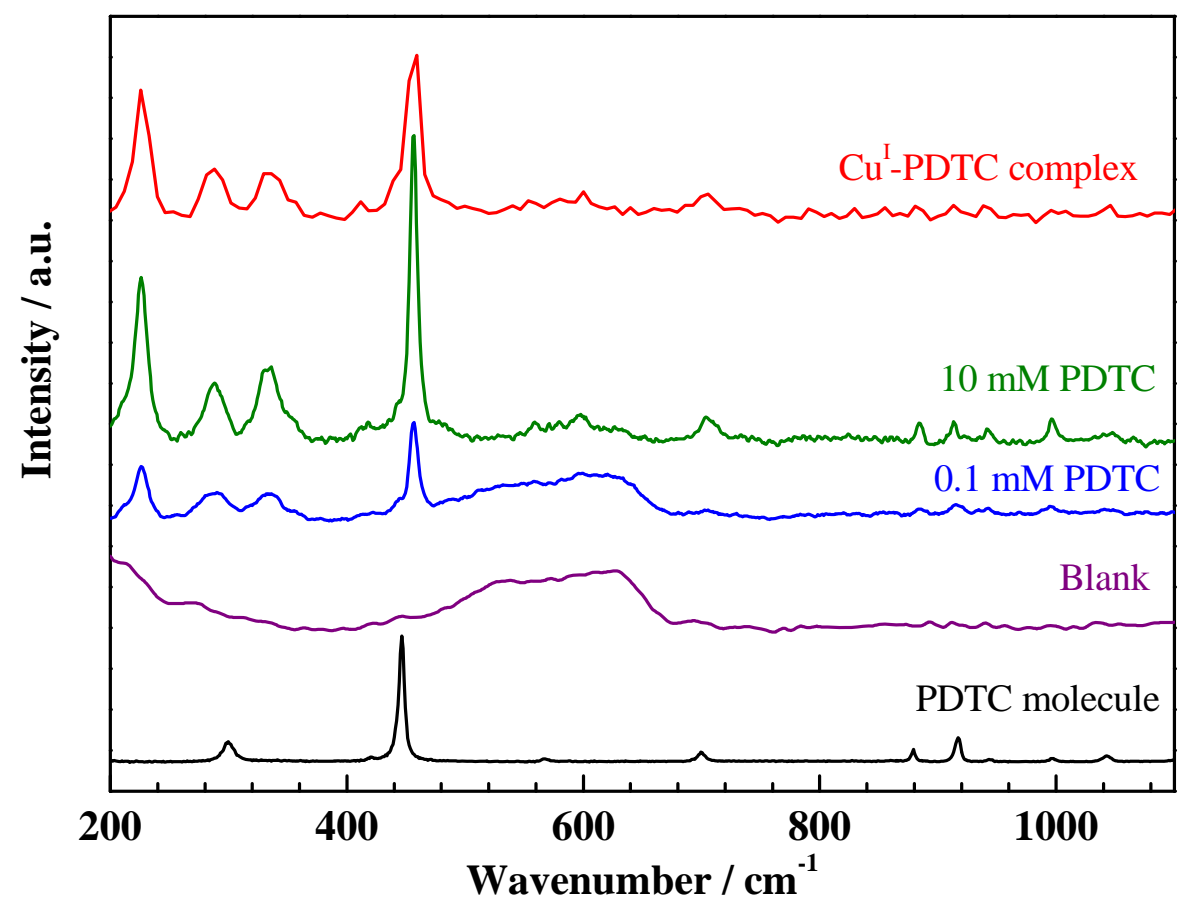

Figure 13: Raman spectra collected on the PDTC molecule, $\mathrm{Cu}^{\mathrm{I}}$-PDTC complex and on the copper electrode after $24 \mathrm{~h}$ immersion in $0.2 \mathrm{~g} \mathrm{~L}^{-1} \mathrm{NaCl}$ without or with $0.1 \mathrm{mM}$ or $10 \mathrm{mM}$ PDTC. 


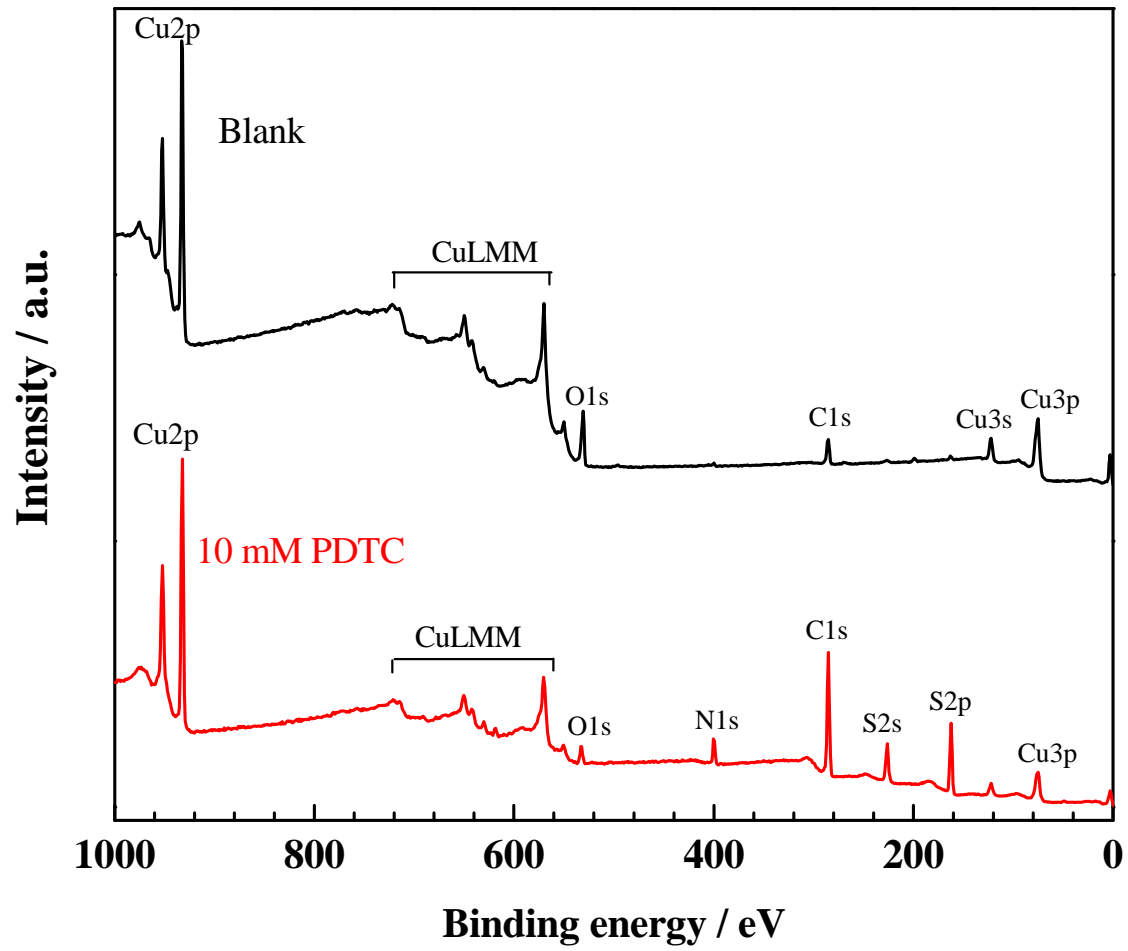

Figure 14: Survey XPS spectra of copper electrode after $24 \mathrm{~h}$ immersion in $0.2 \mathrm{~g} \mathrm{~L}^{-1} \mathrm{NaCl}$ without or with $0.1 \mathrm{mM}$ or $10 \mathrm{mM}$ PDTC. 


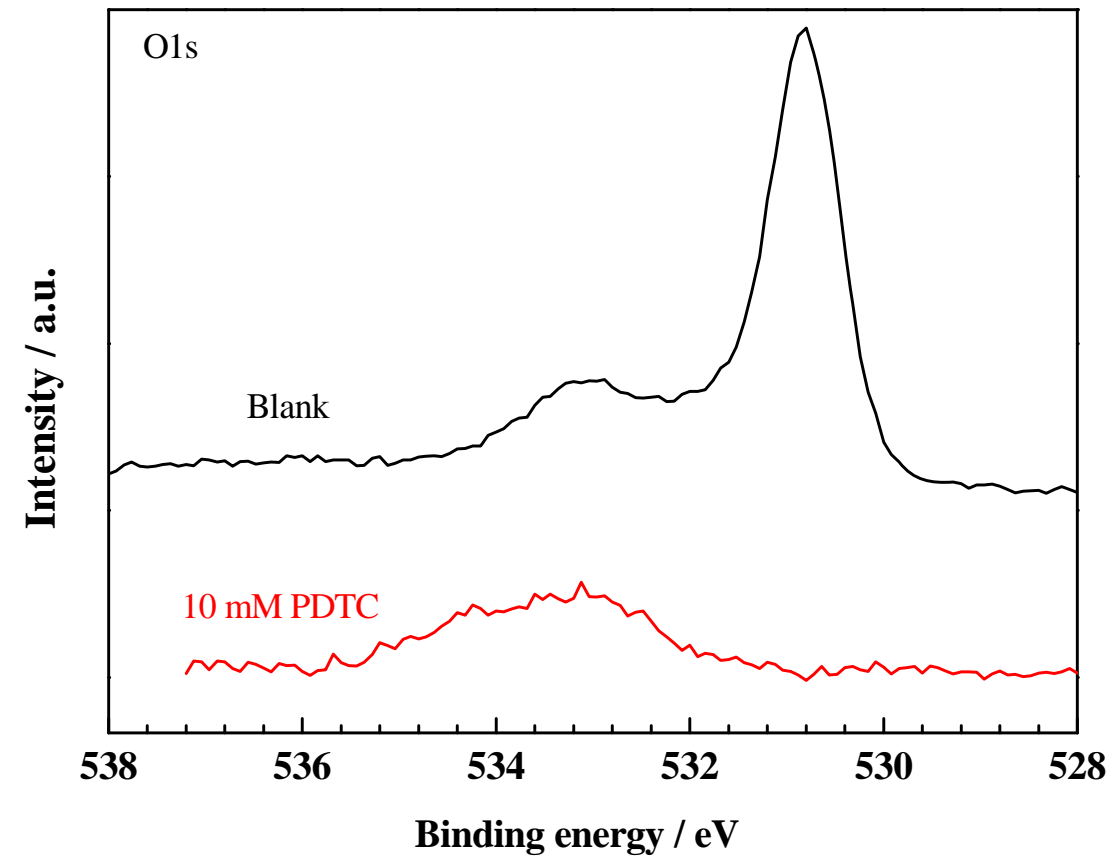

Figure 15: O1s spectra of Cu electrode after $24 \mathrm{~h}$ immersion in $0.2 \mathrm{~g} \mathrm{~L}^{-1} \mathrm{NaCl}$ without or with $0.1 \mathrm{mM}$ or $10 \mathrm{mM}$ PDTC. 

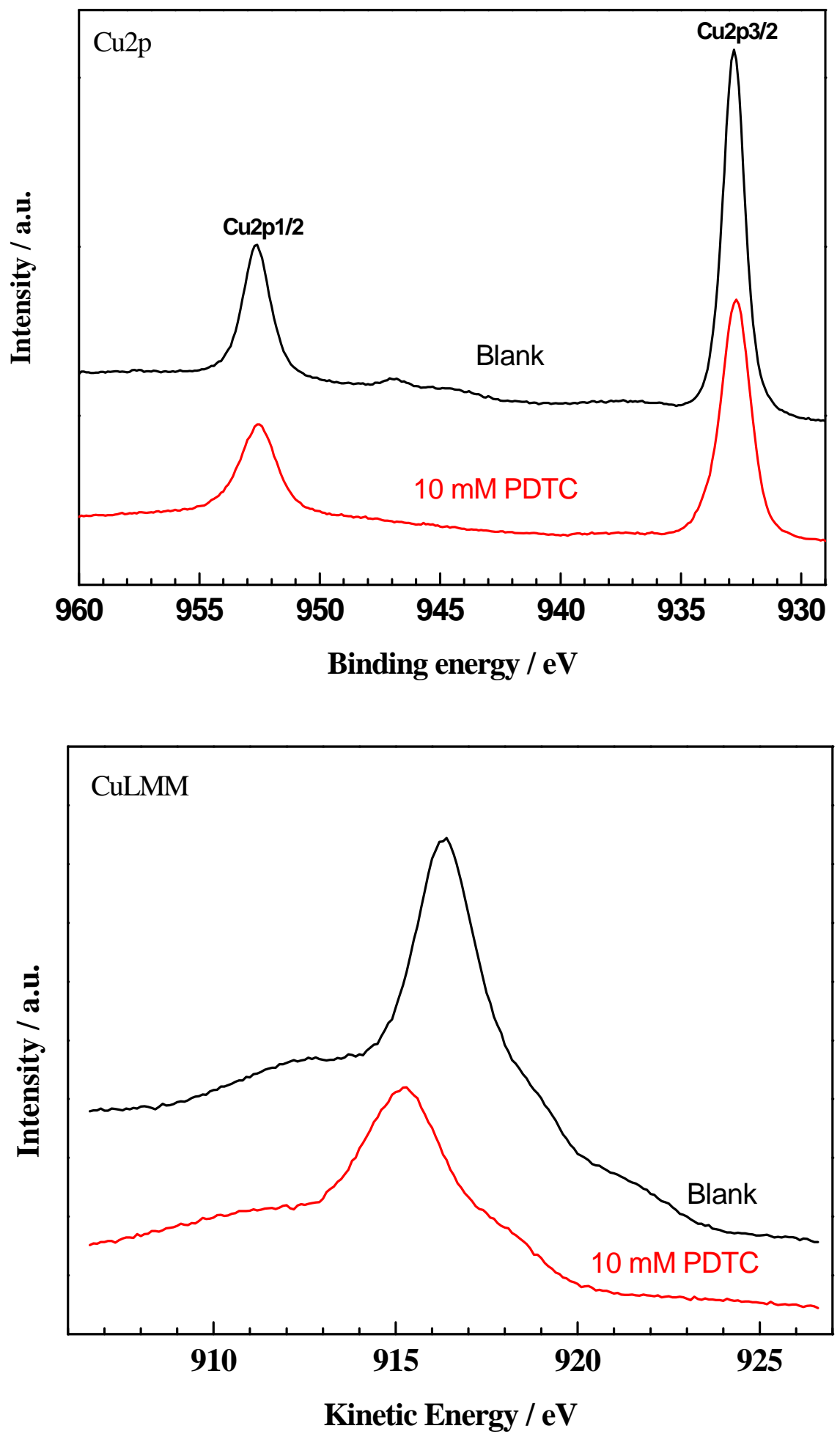

Figure 16: Cu2p and CuLMM spectra of Cu electrode after $24 \mathrm{~h}$ immersion in $0.2 \mathrm{~g} \mathrm{~L}^{-1} \mathrm{NaCl}$ without or with $0.1 \mathrm{mM}$ or $10 \mathrm{mM}$ PDTC. 